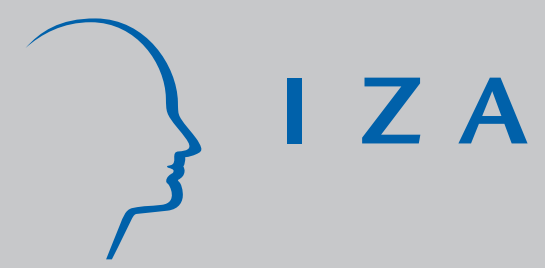

IZA DP No. 8729

Trends in Earnings Inequality and Earnings Instability among U.S. Couples: How Important Is Assortative Matching?

Dmytro Hryshko

Chinhui Juhn

Kristin McCue

December 2014 


\title{
Trends in Earnings Inequality and Earnings Instability among U.S. Couples: How Important Is Assortative Matching?
}

\author{
Dmytro Hryshko \\ University of Alberta
}

Chinhui Juhn

University of Houston, NBER and IZA

Kristin McCue

U.S. Census Bureau

\section{Discussion Paper No. 8729 \\ December 2014}

\author{
IZA \\ P.O. Box 7240 \\ 53072 Bonn \\ Germany \\ Phone: +49-228-3894-0 \\ Fax: +49-228-3894-180 \\ E-mail: iza@iza.org
}

\begin{abstract}
Any opinions expressed here are those of the author(s) and not those of IZA. Research published in this series may include views on policy, but the institute itself takes no institutional policy positions. The IZA research network is committed to the IZA Guiding Principles of Research Integrity.

The Institute for the Study of Labor (IZA) in Bonn is a local and virtual international research center and a place of communication between science, politics and business. IZA is an independent nonprofit organization supported by Deutsche Post Foundation. The center is associated with the University of Bonn and offers a stimulating research environment through its international network, workshops and conferences, data service, project support, research visits and doctoral program. IZA engages in (i) original and internationally competitive research in all fields of labor economics, (ii) development of policy concepts, and (iii) dissemination of research results and concepts to the interested public.
\end{abstract}

IZA Discussion Papers often represent preliminary work and are circulated to encourage discussion. Citation of such a paper should account for its provisional character. A revised version may be available directly from the author. 


\section{ABSTRACT \\ Trends in Earnings Inequality and Earnings Instability among U.S. Couples: How Important Is Assortative Matching?*}

We examine changes in inequality and instability of the combined earnings of married couples over the 1980-2009 period using two U.S. panel data sets: Social Security earnings data matched to Survey of Income and Program Participation panels (SIPP-SSA) and the Panel Study of Income Dynamics. Relative to male earnings inequality, the inequality of couples' earnings is both lower in levels and rises by a smaller amount. We also find that couples' earnings instability is lower in levels compared to male earnings instability and actually declines in the SIPP-SSA data. While wives' earnings played an important role in dampening the rise in inequality and year-to-year variation in resources at the family level, we find that marital sorting and coordination of labor supply decisions at the family level played a minor role. Comparing actual couples to randomly paired simulated couples, we find very similar trends in earnings inequality and instability.

JEL Classification: J1, J2, J3

Keywords: inequality, instability, matching

Corresponding author:

Chinhui Juhn

Department of Economics

University of Houston

Houston, TX 77204-5882

USA

E-mail: cjuhn@uh.edu

\footnotetext{
* This research was supported by the U.S. Social Security Administration through grant \#10-M-983631-01 to the National Bureau of Economic Research as part of the SSA Retirement Research Consortium. Any opinions and conclusions expressed herein are those of the authors and do not necessarily represent the views of the U.S. Census Bureau, the Social Security Administration, any other agency of the Federal Government, or the NBER. All results have been reviewed to ensure that no confidential information is disclosed. We thank Martha Stinson and Gary Benedetto for their help with understanding the data.
} 


\section{Introduction}

The U.S. labor market experienced a tremendous rise in male earnings inequality over the past four decades 1 Not only did cross-sectional earnings inequality increase, the withinperson variability of earnings increased as well $2^{2}$ Over the same period there was also a large increase in employment and earnings of women, with particularly dramatic changes for married women. Given these concurrent trends, one important question is the extent to which wives' earnings and changes in family labor supply helped mitigate the rise in male earnings inequality and possibly smoothed over the variability of male earnings. On the other hand, positive assortative matching of spouses is a countervailing force that could contribute to a rise in couples' earnings inequality. In this paper, we address these questions using two different panel data sets of married couples: Social Security earnings data matched to Survey of Income and Program Participation surveys (hereafter, the SIPP-SSA data), and the Panel Study of Income Dynamics (PSID).

Recent papers in the earnings inequality literature have used administrative data sets to reconsider earlier findings based on survey data. Kopczuk, Saez, and Song (2010) use a sample of longitudinal earnings records extracted from Social Security Administration (SSA) data to examine individual earnings inequality since 1937 and find a U-shaped pattern. They also find that earnings mobility increased over time largely due to the upward progress of women through the earnings distribution. Using the same data set and pooling men and women, Sabelhaus and Song (2010) find a decline in the variability of individual earnings. Guvenen, Ozkan, and Song (2014) use these data to study individual earnings risk over the business cycle and find that recessions are characterized by substantial left-skewness of shocks, rather than a simple increase in the variance of idiosyncratic shocks. While these papers have used administrative data to advance the study of individual earnings dynamics, they do not study couples' earnings. SIPP data identify married couples and so allow us to measure the combined earnings of spouses. Thus, a major contribution of this study is to use a large administrative panel data set to investigate family earnings dynamics.

This paper also contributes to the literature that examines the role of wives' earnings in household earnings inequality. Cancian, Danziger, and Gottschalk (1993), Cancian and Reed (1999), Hyslop (2001), Devereux (2004), Pencavel (2006a), and Pencavel (2006b) examine the impact of wives' earnings on family earnings inequality and find an equalizing impact. Hyslop

\footnotetext{
${ }^{1}$ See, for example, survey articles Autor and Katz (1999) and Autor, Katz, and Kearney (2008). More recent papers documenting inequality trends include Blundell, Pistaferri, and Preston (2008), and Heathcote, Perri, and Violante (2010).

${ }^{2}$ Gottschalk and Moffitt (1994) first documented the rise in the within-person variability of earnings, referred to in the literature as "earnings instability." Other papers using alternative data sets and methods confirmed Gottschalk and Moffitt's basic findings: earnings instability increased dramatically during the 1970s and reached a peak during the 1982 recession but since that period stabilized to the level observed prior to 1982see, for example, Cameron and Tracy (1998) and Haider (2001).
} 
(2001), in particular, provides a thorough study examining separately the impact of wives on permanent and transitory components of earnings, and allowing for endogenous labor supply responses. He finds that spouses' earnings are positively correlated, largely due to permanent components of wages and associated labor supply responses. The cross-correlations in earnings are lower than in wages, consistent with either a strong income effect or offsetting labor supply behavior among couples. One potential drawback to his study is that he selects couples who are continuously employed, thereby largely ignoring labor supply decisions at the extensive margin. Similar to Hyslop (2001) we use panel data to study couples' earnings dynamics, examining separately changes in long-run earnings inequality and earnings instability. In contrast to Hyslop (2001) we include couples where wives have zero earnings to incorporate earnings dynamics arising from wives' participation decisions $!^{3}$

Earnings of spouses may be positively correlated because of positive assortative mating on education (Mare (1991), Pencavel (1988)). Moreover, this type of marital sorting may result in increasing correlation of spouses' earnings as women become more strongly attached to the labor force. Along these lines, Greenwood, Guner, Korchakov, and Santos (2014) find positive assortative matching to have been a major contributing factor to rising household income inequality. Earnings of spouses also may co-vary due to coordinated labor supply decisions. For example, an increase in husband's wage may reduce wives' hours if there is a large income effect. Spouses may also specialize in the market or the home when young children are present, reflecting the fact that time at home for husband and wife are likely to be substitutes at this stage of the life cycle (see Lundberg 1988). Wives may also increase labor supply temporarily to compensate for husbands' job loss, the so-called "added worker effect" (Lundberg (1985) and Stephens (2002)). Such adjustments imply a negative correlation between husbands' and wives' earnings that may affect both transitory and permanent variances.

To gauge the importance of matching and joint labor supply decisions, we build counterfactual earnings inequality and instability measures by drawing random matches of married men and married women and constructing the same measures using their combined earnings. If earnings inequality and instability measures for the randomly rematched couples differ substantially from those of actual couples, this would point to an important role for matching and/or joint labor supply decisions. Our findings are as follows:

1. We find that inequality in the combined earnings of couples grew over the 1980-2009 period based on evidence from both the PSID and the SIPP-SSA data. Inequality of couples' combined earnings is lower than inequality of husbands' earnings, and while it has grown over time, it has done so more slowly than inequality of husband's earnings.

\footnotetext{
${ }^{3}$ Wages and hours are not separately available in the SSA earnings data, however, which limits our focus to earnings only.
} 
2. Instability of couples' earnings actually declined in the SIPP-SSA data while it started at a lower level but increased in the PSID. In both data sets, however, earnings instability is lower for couples than for husbands and rises by a smaller amount (PSID) or falls (SIPP-SSA) compared to male earnings instability.

3. We find that coordination of spouses' labor supply decisions and positive assortative matching play a minimal role in determining overall earnings inequality and earnings instability among couples. We find very similar trends for actual and simulated couples, suggesting that who is married to whom is relatively unimportant for the evolution of couples' inequality and instability in the U.S.

The rest of the paper is structured as follows. Section 2 discusses the methodology while Section 3 describes our data sets and the samples used. Section 4 describes earnings inequality and instability trends for individuals and couples. Section 5 compares inequality and instability measures across actual and simulated couples to examine the importance of spousal matching and family labor supply decisions. Section 6 examines the robustness of our results to alternative sample restrictions used by other authors. Section 7 summarizes our findings.

\section{Methodology}

To help describe our basic approach, we begin with the following statistical model:

$$
\begin{array}{r}
y_{i t}=X_{i t}^{\prime} \beta_{t}+\epsilon_{i t} \\
\epsilon_{i t}=p_{t}^{\mu} \mu_{i t}+p_{t}^{v} v_{i t},
\end{array}
$$

where $y_{i t}$ denotes individual $i$ 's log annual earnings and $X_{i t}$ denotes observed characteristics. Residual earnings, $\epsilon_{i t}$, are assumed to consist of a permanent component, $\mu_{i t}$, and a transitory component, $v_{i t}$, which is assumed to be independent of $\mu_{i t} .4$ The term $p_{t}^{\mu}$ represents factorloading on the person-specific permanent component, such as returns to individual skills or human capital, which may vary by year. Similarly, the term $p_{t}^{v}$ reflects factor-loading on the person-specific transitory component. The transitory component, $v_{i t}$, may comprise purely transitory i.i.d. shocks and/or a serially correlated transitory process. In the data, much of the variation in individual earnings is due to the variation in $\epsilon_{i t}$. Understanding the crosssectional variation of $\epsilon_{i t}$ is, therefore, important for understanding the cross-sectional variation of earnings, $y_{i t}$. In the following, we refer to the cross-sectional variance of residual earnings, $\epsilon_{i t}$, as "earnings inequality." We run a pooled regression of individual log earnings on a

\footnotetext{
${ }^{4}$ The permanent component is normally modeled as a person-specific fixed effect, or a sum of the fixed effect and a martingale component.
} 
polynomial in age in $X_{i t}$ to control for the predictable life-cycle effects and year dummies to control for aggregate trends in earnings. Our measure of inequality, therefore, will reflect earnings inequality due to idiosyncratic individual labor market shocks as well as earnings inequality due to differential returns to observable characteristics among individuals of the same age.

To gauge the importance of permanent versus transitory components of earnings inequality we follow the methodology of Kopczuk, Saez, and Song (2010). In particular, define the average of $\epsilon_{i t}$ in a five-year window as $\bar{\epsilon}_{i t}=\sum_{j=t-2}^{j=t+2} \epsilon_{i j}$. As in Kopczuk, Saez, and Song (2010), we refer to the cross-sectional variance of $\bar{\epsilon}_{i t}$, $\operatorname{var}^{i}\left(\bar{\epsilon}_{i t}\right)$, as the "permanent variance" at time $t$, and the cross-sectional variance of $\epsilon_{i t}-\bar{\epsilon}_{i t}$ as the "transitory variance" at $t$. To interpret the measures, consider the case when $\mu_{i t}$ is a time-invariant person-specific effect $\mu_{i}$, the factor-loadings $p_{t}^{\mu}$ and $p_{t}^{v}$ are constant, and $v_{i t}$ is an i.i.d. shock. The variance of $\bar{\epsilon}_{i t}$ will then come close to the variance of the permanent component, $\mu_{i}$, provided that a five-year average of the transitory shocks $v_{i t}$ has negligible variance. In a more general case, when the permanent component is modeled as a random walk or a highly persistent process, the variance of $\epsilon_{i t}-\bar{\epsilon}_{i t}$ may contain the contribution of both permanent and transitory shocks, as also noted by Kopczuk, Saez, and Song (2010). However, $\bar{\epsilon}_{i t}$ will put a larger weight on shocks to the permanent component, more so if the averaging window is larger $5^{5}$

We further expand our statistical model of earnings to apply to couple $c$ :

$$
\begin{aligned}
y_{c t}^{m} & =X_{c t}^{m} \beta_{t}+\epsilon_{c t}^{m} \\
\epsilon_{c t}^{m} & =p_{t} \mu_{c t}^{m}+v_{c t}^{m} \\
y_{c t}^{f} & =X_{c t}^{f} \beta_{t}+\epsilon_{c t}^{f} \\
\epsilon_{c t}^{f} & =p_{t} \mu_{c t}^{f}+v_{c t}^{f},
\end{aligned}
$$

where the superscripts $m$ and $f$ refer to the husband and the wife respectively. The residual variance of couples' earnings will reflect the variances of the head's and wife's permanent and transitory components as well as the covariances between their permanent and transitory components. In practice, we run a regression of (log of) $y_{c t}^{m}+y_{c t}^{f}$ on a polynomial in head's age and year dummies. Our residual, $\epsilon_{c t}$, is, therefore, a combination of residual earnings of the head and wife. As with our previous measures, we use the variance of $\epsilon_{c t}$ averaged over a five-year window to measure the permanent variance of couples' earnings, while the variance of $\epsilon_{c t}-\bar{\epsilon}_{c t}$ measures the transitory variance at time $t$.

The permanent variance of couples' earnings, call it $\psi_{\bar{\epsilon}_{c t}}$, will include the effects of com-

\footnotetext{
${ }^{5}$ Note, however, that there is a tradeoff in selecting a wider window - the wider window will be more informative on the rise of inequality due to permanent or more persistent shocks but it also entails selecting a sample of more stable couples which is likely to be less representative of the overall population of U.S. families.
} 
bining income draws from the husbands' and wives' individual earnings distributions as well as the effects of spousal matching and coordinated labor supply. $\left.\right|^{6}$ Due to positive assortative mating, we expect matching to raise inequality. In addition, the impact of positive assortative matching on earnings inequality may have increased over time due to rising labor force participation of women. Even if the most able men and women are matched to each other, this will likely have little impact on couples earnings inequality if women do not participate in the labor force. As women participate in the labor force, the most able women married to the most able men are likely to have higher earnings relative to the less able women married to less able men. These channels are highlighted in a recent paper, Greenwood, Guner, Korchakov, and Santos (2014). In contrast to matching, coordinated labor supply is expected to reduce inequality as women may increase work to compensate for husband's job loss or specialize in home production while husbands specialize in working outside the home.

To gauge the importance of matching and joint labor supply decisions, we build counterfactual permanent variances by drawing random matches of married men and married women and constructing the same measures using their combined earnings. First, to isolate the effect of joint labor supply decisions from marital sorting, we build a counterfactual permanent variance, $\psi_{\bar{\epsilon}_{c t}}^{1}$, by grouping couples based on observable characteristics such as education of the husband and wife and age of husband and wife in addition to year, and randomly matching couples within groups.7 We refer to these re-matched couples as "conditionally swapped" cou-

\footnotetext{
${ }^{6}$ While we focus on the variance of log earnings to make our results comparable to many of the previous studies, that measure does not neatly decompose into terms involving the variance contributions of each spouse plus a covariance term since our samples also include spouses with zero earnings, logs of which are undefined. It may be instructive to consider the following decomposition of couples' earnings based on the squared coefficient of variation. Letting $y$ denote the level of earnings:

$$
\begin{aligned}
\mathrm{CV}^{2}\left(y_{c t}\right) & =\frac{\operatorname{var}\left(y_{c t}\right)}{\left(\bar{y}_{t}\right)^{2}}=\frac{\operatorname{var}\left(y_{c t}^{m}\right)+\operatorname{var}\left(y_{c t}^{f}\right)+2 \operatorname{cov}\left(y_{c t}^{m}, y_{c t}^{f}\right)}{\left(\bar{y}_{t}^{m}+\bar{y}_{t}^{f}\right)^{2}} \\
& =\frac{\left(\bar{y}_{t}^{m}\right)^{2}}{\left(\bar{y}_{t}^{m}+\bar{y}_{t}^{f}\right)^{2}} \mathrm{CV}^{2}\left(y_{c t}^{m}\right)+\frac{\left(\bar{y}_{t}^{f}\right)^{2}}{\left(\bar{y}_{t}^{m}+\bar{y}_{t}^{f}\right)^{2}} \mathrm{CV}^{2}\left(y_{c t}^{f}\right)+\frac{2 \operatorname{cov}\left(y_{c t}^{m}, y_{c t}^{f}\right)}{\left(\bar{y}_{t}^{m}+\bar{y}_{t}^{f}\right)^{2}} .
\end{aligned}
$$

One can decompose this measure of inequality in couples' earnings into terms involving inequality measures for husbands and wives plus a covariance term. The covariance term incorporates the effect of positive assortative matching and offsetting labor supply behavior. When we randomly rematch couples, we effectively set this covariance term to zero. The difference between inequality measures of actual couples and those of simulated couples will indicate the importance of couple-specific matching and joint labor supply behavior.

${ }^{7}$ More precisely, for the SIPP-SSA data, we define 12 education classifications for the couple based on cross-classification of five education groups for the husbands and wives (less than high school, high school graduate, some college, bachelor's degree, advanced degree). We collapse smaller off-diagonal cells to reduce the 20 off-diagonal cells to 7: 1) one spouse is a high-school graduate and the other did not finish high school; 2) women with at most a high-school education married to men who have at least some college; 3) women with a college degree married to men with at most some college; 4) women with an advanced degree married to men with a bachelor's degree; 5) men with an advanced degree married to women with a bachelor's degree; 6) women with some college married to men with at most a high-school education; 7) women with some college married to men with at least a bachelor's degree. We further define 3 age groups for husbands (25-34, 35-44, 45-59), and 3 relative-age groups for wives: 1 ) wife is 3 or more years younger than husband ; 2) wife is very
} 
ples. Since the difference between the actual variance and this counterfactual variance isolates

the role of offsetting joint labor supply, we expect $\psi_{\bar{\epsilon}_{c t}}^{1}$ to be higher than the actual variance. ${ }^{8}$

To further isolate the role of matching, we build a second counterfactual variance, $\psi_{\bar{\epsilon}_{c t}}^{2}$, by randomly re-matching married men and married women in a given year without conditioning on either education or age. We refer to these re-matched couples as "unconditionally swapped." The difference between "conditionally swapped" and "unconditionally swapped" couples reflects matching so we expect the counterfactual variance $\psi_{\bar{\epsilon}_{c t}}^{2}$ to be lower than $\psi_{\bar{\epsilon}_{c t}}^{1}$. The difference between "unconditionally swapped" and actual couples, $\psi_{\bar{\epsilon}_{c t}}-\psi_{\bar{\epsilon}_{c t}}^{2}$, reflects the net impact of both matching and joint labor supply. We construct analogous measures for the transitory variance, allowing us to similarly isolate the roles of matching and joint labor supply!

\section{Data}

\subsection{SIPP-SSA matched data}

Our first data set combines confidential administrative earnings records with Survey of Income and Program Participation (SIPP) survey data. The SIPP is a series of nationally representative U.S. panel data sets, with sample sizes ranging from about 14,000 to 52,000 households per panel. Each of the panels we use collects information in 8-16 four-month waves. Our sample of individuals is drawn from respondents to the 1984, 1990-1993, 1996, 2001, 2004, and 2008 SIPP panels who provided the information needed to validate matches to Social Security Administration (SSA) earnings records. For these individuals, we have annual earnings for 1978-2011 based on summaries of earnings on jobs recorded in SSA's Master Earnings File (MEF). The primary source of the MEF earnings information is W-2 records, but self-employment earnings are also included. We include employees' contributions

close in age to husband (2 years younger-1 year older); 3 ) wife is more than 1 year older than husband. Overall, this results in $108(12 \times 9)$ groups for each year. With the SIPP-SSA data, we do not have current state of residence except during a sample couple's SIPP panel, so we are limited to using age, education, and year to do the rematching. For the PSID sample, since it is smaller, we define four age groups and four education groups. The age groups are based on whether the head and wife are aged below 40 or above 40; the education groups are based on whether the head and wife have more than 15 years of schooling, or 15 years of schooling or less. We have examined the results of using these more aggregate categories with the SIPP-SSA data and find that the results are very similar to those based on the more detailed categories.

${ }^{8}$ The assumption here is that observable characteristics such as education and age sufficiently control for matching. It is possible that husbands and wives match on characteristics we do not observe in the data. It may also be the case that husbands and wives experience (positively) correlated shocks due to local labor market conditions. Both of these effects would work against us finding a negative correlation due to joint labor supply decisions.

${ }^{9}$ We create 100 such simulations. For each simulation, we take the set of husbands from couples meeting the selection criteria and randomly assign a pseudo-wife by sampling from among the wives from the available set of couples. For the conditional resampling, we stratify as described in footnote 7 . 
to deferred compensation plans as part of our earnings measure. We obtain marital histories, educational attainment, and women's fertility histories from data collected in the SIPP. Age and gender are based on combined information from the SIPP and SSA sources.10

We restrict our sample in each year to individuals aged 25-59. While detailed survey information on employment and earnings are collected for each individual only over the relatively short window of their SIPP panel, from the administrative records we have annual earnings for each year between 1978 and 2011. Our base sample includes all matched SIPP respondents in any years in which they meet the 25-59 age restriction. Thus for someone who was 50 when interviewed in the 1990 SIPP panel, we use earnings for 1978-1999, while for someone who was 20 in 1990 we use earnings for 1995-2011. In total we have about 4.6 million person/year observations, or roughly 135,000 people per year.

Where we condition on marital status, we only use earnings for years in which we can determine whether or not someone is married. The marital history information collected in the second wave of each SIPP panel, along with updates from changes in later waves of that panel, gives us information on an individual's marital status for years leading up to and during that individual's SIPP panel. While we have earnings for years after the earlier panels are over, we do not know marital status for those years. Thus when we condition on marital status we have much smaller samples at the end of our period than at the beginning because in later years we can only use the most recent panel(s). For example, in 2004-2007 we can only identify married men and women if they are members of the 2004 or 2008 SIPP panels, while in 1978 we can in principle use data on any matched person born between 1919 and 1953 from any of our SIPP panels as long as they provided a marital history.

One further complication in examining the earnings of married couples is that we only have earnings for both members of couples if they are in the same household in the second wave of their SIPP panel. For a sample member who had a marriage that ended before the start of the SIPP panel, we have earnings for that sample member and know in which prior years they were married, but we do not have any information on their former spouse. Thus we cannot, for example, look at the combined couples earnings during former marriages because we are missing earnings for their former spouse. For this reason, in our estimates for both actual and counterfactual couples, we use data only on members of couples with linked earnings for both spouses 111 Because our sample pools data from several SIPP samples, we do not

\footnotetext{
${ }^{10}$ The results presented here are based on confidential data from Version 6.0 of the SIPP Gold Standard File. External researchers can access related data through the public-use SIPP Synthetic Beta (SSB) files, and Census will validate results obtained from the SSB on the internal, confidential version of these data (the Completed Gold Standard Files). For more information, please visit http://www.census.gov/programssurveys/sipp/methodology/sipp-synthetic-beta-data-product.html. The U.S. Census Bureau also supports external researchers use of some of these data through the Research Data Center network (www.census.gov/ces/rdcresearch).

${ }^{11}$ This means that long-duration marriages will be over-represented in our sample, as a woman married in
} 
use SIPP survey weights in our analysis, so the results cannot be assumed to be nationally representative.

\subsection{PSID data}

Our second data set is the Panel Study of Income Dynamics (PSID) which has been used in numerous empirical papers to document trends in earnings inequality and instability in the U.S. Given its importance in this literature, results from the PSID provide an important point of comparison for our findings from the less familiar SIPP-SSA administrative earnings data. The PSID was initiated in 1968, interviewing a sample of about 5,000 families representative of the U.S. population (the SRC sample) and a sample of about 2,000 low-income families (the Survey of Economic Opportunity sample). The PSID has followed the original families and their offspring over time, collecting information on earnings, marital status, and a number of other topics. Interviews were conducted annually up to 1997 and have been conducted biennially since then. We use information for the SRC sample during 1978-2011 for our current results.

\subsection{Sample selection}

We make the following sample restrictions in constructing our estimates of both inequality of permanent earnings and earnings instability. For our primary analyses, we select men who are 25-59 years old and had non-zero earnings. We also minimize the effect of outliers by deleting the bottom and top 1 percent of earnings observations. Men in this sample have to satisfy the above conditions for all years of the window in question - so for the five-year window surrounding year $t$, men must satisfy the above conditions for the 2 years before and after $t$, as well as for year $t$ itself. For our couples' samples, we begin with husbands who satisfy the above conditions. We further require that couples be continuously married to each other over the relevant window. Since our focus is on wives' contributions to couples earnings through both wages and labor supply, we include wives who have zero earnings. This restriction is typically used in models that assume full-time working males and females making labor supply decisions at both the extensive and intensive margins - see, for example, Attanasio, Low, and Sanchez-Marcos (2008) and Heathcote, Storesletten, and Violante (2010). We explore sensitivity of our results to alternative restrictions on female and male labor supply in Section 6 .

1980 and interviewed in the 2004 SIPP panel will be included in our couples' sample if still married in 2004, but not if she divorced or became a widow in the intervening years. We do have earnings, education, and age for both men and women who are interviewed after a marriage has ended, but not information on their former spouse. 


\section{Trends in Earnings Inequality and Earnings Instabil- ity}

\subsection{Husbands' earnings}

We begin by presenting estimates for men's earnings. Estimates for all men are useful as a check for consistency with others' findings, but we also look at husbands separately because their earnings directly contribute to couples' earnings.

Figure 1 shows the well-known rise in the permanent variance of male earnings that has been documented in numerous studies. The top panel gives estimates based on the SIPP-SSA data while the bottom panel gives estimates based on the PSID. Both our SIPP-SSA and PSID estimates begin with the 5-year average centered on year 1980 and end with 2009, based on data from years 1978-2011. After 1997 the PSID switched to biennial reporting which makes comparability difficult. In addition, the PSID went through a major overhaul between the 1993 and 1994 surveys, switching to computer-assisted telephone interviewing, automated editing of data, and changing the income questions. Thus, the changes encompassing these years have to be interpreted with caution 12

While the levels of the permanent variance differ across the two data sets (higher in the SIPP-SSA, perhaps because the PSID measure of labor income includes additional components that smooth the income from wages and salaries), both data sets show an increase in trend. In the SIPP-SSA data, the variance increased by 82 percent over the period 1980-2009 for all men and almost doubled for husbands (see Table 1). In the PSID, the variance more than doubled for all men and rose by 91 percent for husbands over the same period.

Figure 2 describes transitory earnings variation among all men and among husbands. As documented in Dynan, Elmendorf, and Sichel (2012) and Shin and Solon (2011) and illustrated in the bottom panel of Figure2, earnings instability of men as measured in the PSID was stable during the 1980s but rose in the 1990s and 2000s. In contrast, there is cyclical variation in male earnings instability in the SIPP-SSA estimates but little trend. This pattern is also found for men by Kopczuk, Saez, and Song (2010) and Dahl, DeLeire, and Schwabish (2008) (both using similar SSA earnings data for SSA's Continuous Work History sample). Comparing across data sets, Celik, Juhn, McCue, and Thompson (2012) find that the recent rise in volatility found in the PSID is somewhat anomalous. Monti and Gathright (2013) find an increase in transitory earnings variation for men in the 1990s based on SIPP collected earnings data, but a decrease for the same individuals when using SSA earnings data for the same years.

\footnotetext{
${ }^{12}$ See discussion in Dynan, Elmendorf, and Sichel (2012).
} 


\subsection{Couples' earnings}

How do inequality and instability of couples' earnings compare to those for husbands? Figure 3 gives a comparison of the trends in the permanent variances, with the corresponding numbers appearing in Table 1. According to both data sources, inequality of couples' earnings is both lower in levels and has increased at a slower rate over the period of our analysis. In 1980, the variance of couples' earnings in SIPP-SSA data is approximately 10 percent lower. In 2009, it is about 30 percent lower. Over the period, the permanent variance of couples' earnings rose by about 70 percent while the permanent variance of husbands' earnings almost doubled. While overall levels of inequality are lower in the PSID, the trends are similar, as illustrated in the bottom panel. In the PSID, couples' earnings variance increased by 65 percent from 1980 to 2009 while husbands' earnings variance increased by 91 percent. Wives' earnings reduce inequality because, while husbands' and wives' earnings are positively correlated, the corrrelation is far from one. Combining draws from two individual earnings distributions dampens both the level and the rise in the variance.

Figure 4 and Table 2 present estimates of the instability of couples' combined earnings along with instability of husbands' earnings. Couples' earnings have lower levels of instability than the earnings of husbands alone. As we similarly found for individual earnings, the two data sets show different trends in the instability of couples' earnings over this period. The SIPP-SSA estimates suggest that instability of couples earnings has actually fallen since 1980,

while the PSID shows an increase. Even in the PSID, however, the increase in instability of couples' earnings is more muted than the increase in instability of husbands' earnings.

Comparison of male earnings with couples' earnings suggests that wives have played a significant role not only in mitigating the rise of permanent earnings inequality but also in smoothing over earnings instability at the family level. In the next section we explore to what extent coordinated labor supply decisions and positive assortative matching contributed to, or possibly hindered, this outcome.

\section{The Impact of Coordination and Matching on Cou- ples' Earnings Inequality and Instability}

To gauge the importance of marital sorting and coordination, we now turn to comparing earnings instability and inequality measures for actual couples to our counterfactual estimates based on randomly matched couples. We start by defining a sample of eligible husbands and wives for a given five-year window using the same exclusion restrictions described above. We then use random sampling to select a counterfactual wife for each husband for that particular window, drawing wives with replacement from the same set of couples. For "conditionally 
swapped" couples, we draw counterfactual wives only from among couples in the same education and age cell $[13$ For "unconditionally swapped" couples, we draw a random wife from the entire set of eligible couples. We then combine the husband's and counterfactual-wife's earnings to obtain couple's earnings for the rematched couple for years $t-2$ to $t+2$. We regress that earnings measure on a fourth degree polynomial in age and year dummies. Residuals from this regression are then used to construct permanent and transitory variances for each simulation.

Figure 5 illustrates the permanent variance of actual couples' earnings as well as earnings of rematched couples. We find that relative to unconditionally matched couples, conditionally matched couples have somewhat higher variance of combined earnings, reflecting positive assortative matching on education and age. Relative to the conditionally matched couples, actual couples have slightly lower variance of earnings which is consistent with coordinated offsetting labor supply behavior. That is, comparing couples within a group defined by the ages and education levels of both spouses, husbands with relatively high earnings tend to have wives with relatively low earnings. But this pattern is not particularly strong. The key observation to take away from these graphs is that relative to the gap between male earnings variance and couples' earnings variance, the differences between the other three lines are very small.

Table 1 shows that in the SIPP-SSA data, actual couples' earnings variance increased by about 69 percent from 1980 to 2009. If we randomly match couples, thereby shutting down positive assortative matching and joint labor supply behavior, couples' earnings variance increases by about 67 percent. Given that the measures start at similar levels, this suggests that about 2 out of the 69 percent rise can be attributed to the combined effects of matching and coordinated labor supply. The differences in trend between the actual and the simulated couples in the PSID are even smaller. Our results are in stark contrast to Greenwood, Guner, Korchakov, and Santos (2014) who find that positive assortative matching can account for the entire increase in household income inequality since 1960. Our results are more consistent with Eika, Mogstad, and Zafar (2014) who report that changes in assortative mating played a minor role in the rise in household income inequality.

In the absence of offsetting labor supply, assortative matching should manifest itself in high correlation of spousal permanent earnings. In Figure 6, we plot the trends in the correlation of five-year averages of the husband's and his spouse's earnings in both sets of data, where the spouse is either actual or randomly drawn ${ }^{14}$ For actual couples, we find that on average over this period spousal earnings are positively but weakly correlated with each other. We find a positive trend in the correlation over time in the SIPP-SSA data, but not in the PSID.

\footnotetext{
${ }^{13}$ As defined in footnote 7 .

${ }^{14}$ To accommodate observations with zero female earnings during a five-year window, we take the five-year averages of levels rather than logs.
} 
Conditionally matched couples have low but positively correlated earnings which suggests that age and education capture the general pattern in assortative matching well. In the SIPPSSA estimates we find that the correlation for actual couples grows more quickly than that for conditionally matched couples over this period, particularly over the 1980-1995 period. This pattern is consistent with an increase in assortative matching, though the modest rise in the conditionally matched correlation indicates that an increase in assortative matching on observables played a modest role 15 By construction, unconditionally matched couples' earnings are uncorrelated.

Figures 7 and 8 repeat the comparison in Figure 5, splitting the sample into couples with "less educated" and "more educated" husbands, respectively ${ }^{16}$ The corresponding numbers are presented in Table 3 and Table 4. We find that the overall difference in permanent earnings variance between actual and rematched couples masks somewhat different patterns among couples with more and less education. As shown in Table 4 , among more educated couples the variance of earnings for rematched couples is higher than that for actual couples suggesting that there may be offsetting labor supply behavior. But again, the key point is that neither matching nor joint labor supply behavior make particularly large contributions to the rising trend in the permanent variance of couples' earnings.

Figure 9 provides the same comparison between actual and rematched couples for earnings instability. The gap between male earnings instability and couples' earnings instability is even more pronounced relative to the very minor differences between the actual and randomly matched couples.

What conclusions can we draw regarding wives' contributions to earnings inequality and earnings instability among couples? We find that wives' earnings play an important role both in dampening the cross-sectional inequality of resources for married couples, and in offsetting transitory shocks to those resources. This appears simply due to the fact that earnings of spouses are not strongly positively correlated. Surprisingly we find that the covariance of couples' earnings that arises due to positive assortative matching and coordination in labor supply is relatively minor.

\footnotetext{
${ }^{15}$ A decline in the importance of coordinated labor supply would also be consistent with the observed pattern.

16 "More educated" individuals are defined as those who have at least a bachelor's degree, while "less educated" are the rest. Here, sampling for the "unconditionally" rematched couples does condition on whether or not the husband is a college graduate, so it incorporates part of the effects of positive assortative matching.
} 


\section{Robustness}

\subsection{Gini coefficients as measures of inequality}

We have so far focused exclusively on the variance of (average) log earnings as our measure of permanent earnings inequality. It may be the case, however, that other inequality measures are more sensitive to low or high earnings observations. Heathcote, Perri, and Violante (2010), for instance, point out that Gini coefficients emphasize the top of the earnings distribution while the variances of logs emphasize the bottom part of the earnings distribution. To the extent that matching differentially affects couples in the lower and upper halves of the distribution, we may be understating the importance of matching. To explore this issue, we redo our matching exercise using Gini coefficients as our measure of inequality. These results are shown in Table 5 and Figure 10. As shown in Table 5, the levels of inequality are more similar across the two data sets when we use the Gini coefficient as our measure of inequality. One possibility is that the SIPP-SSA contains a higher proportion of low earnings observations relative to the PSID. Over the period, the Gini coefficient for husbands' earnings rises by similar amounts in the two data sets - 47 percent in SIPP-SSA and 42 percent in the PSID. The Gini coefficient for couples' earnings for 1980 is only slightly below that for husbands' earnings, but rises more slowly over time, rising by 36 percent in SIPP-SSA and by 31 percent in the PSID. Comparing actual couples to randomly matched couples, we find that positive assortative matching and joint labor supply played a minor role relative to the increase in inequality of couples' earnings. In the SIPP-SSA data, the Gini coefficient of earnings of randomly matched couples rises by about 31 percent whereas it rose by about 36 percent for actual couples. This suggests that at most 5 out of the 36 percent increase can be attributed to matching and joint labor supply.

\subsection{Dropping zero earnings observations for wives}

Next, we explore robustness to dropping zero earnings observations for wives, following the restriction used in Hyslop (2001). Relative to the main sample, this selection limits the effect of coordinated labor supply on the evolution of inequality over time by eliminating couples in which wives enter or exit the labor market in response to shocks or predictable changes in the husband's earnings. ${ }^{17}$ The trends for the permanent variance are plotted in Figure 11. As in the main sample, conditionally matched couples have more unequal incomes than unconditionally matched couples, reflecting the effect of positive assortative matching on inequality. In contrast to the main sample, however, conditionally matched couples are less unequal than actual couples which likely reflects that offsetting labor supply is more operative

\footnotetext{
${ }^{17}$ As in Hyslop (2001), in the PSID we drop observations with hourly wages of more than 100 real 1980-1982 dollars. In the SIPP-SSA data we maintain our exclusion of earnings above the 99th percentile.
} 
at the extensive margin, and that here we have dropped the couples with high-wage males and non-working females present in the main sample.

Also, in contrast to the main sample, husbands and wives who are consistently attached to the labor force have more highly correlated permanent earnings - see Figure 13. Similar to Hyslop (2001), once we select on continuously working couples in the PSID, actual couples have higher earnings inequality than randomly matched couples, though this difference is negligible in the SIPP-SSA results. Our findings in the PSID suggest that adjustments on the extensive margin offset the contribution of positive assortative matching to explaining the level of permanent earnings inequality. However, as illustrated in Figure 11 we find little contribution of matching to the trend in earnings inequality over the longer period in either dataset. This is in contrast to Hyslop (2001) who finds that roughly 23 percent of the rise in couples' permanent earnings inequality over the 1979-1985 period is attributable to matching.

\subsection{Keeping zero earnings observations for husbands}

We further explore robustness to inclusion of men with zero earnings (in one or more years of the 5-year window) in the sample, making our restrictions similar to those used in Greenwood, Guner, Korchakov, and Santos (2014). Greenwood, Guner, Korchakov, and Santos (2014) find that an increase in assortative matching on education and earnings makes an important contribution to the increase in inequality between 1960 and 2005 . It is possible that by restricting the sample to husbands with non-zero earnings, we may be limiting the impact of matching, particularly if husbands with zero earnings are matched to wives with zero or low earnings. We find, however, that relaxing this exclusion has little effect on our conclusions. Even when we include men with zero earnings, we do not find much difference between actual and randomly matched couples in either data set - see Figure 12. For this sample selection, in the PSID, there is some evidence of a higher degree of assortative matching since the mid-1990s relative to the earlier period-see Figure 13. However, since the correlation between spousal earnings is small, positive assortative matching does not affect much the level of inequality for actual versus randomly matched couples as shown in Figure 12. This finding is in contrast to the finding of Greenwood, Guner, Korchakov, and Santos (2014) who argue that assortative matching played an important role in the rise of family inequality from 1960 to 2005.18

\footnotetext{
${ }^{18}$ Greenwood, Guner, Korchakov, and Santos (2014) find, using a sample of U.S. families and singles, that the counterfactual Gini coefficient for randomly matched couples is about $20 \%$ lower than the Gini coefficient observed in the data in 2005, while there's virtually no difference in the Ginis for actual and random couples in 1960. The analysis in our paper differs from theirs, first, in the method and, second, in the data (in particular, we are not including singles). Using PSID data, we replicated their sample selection criteria and followed their method for calculating Gini coefficients for randomly matched couples but, similar to our paper's results, we still didn't find any significant contribution of assortative matching and coordinated labor supply to the trend of inequality. In particular, our estimates for the Gini coefficients for actual and randomly matched couples are, respectively, 0.30 and 0.28 in 1980, and 0.37 and 0.34 in 2005 .
} 


\section{Conclusion}

In this paper we examined trends in the variance of combined earnings of husbands and wives using two alternative panel data sets: annual Social Security earnings data matched to samples from multiple SIPP panels, and the PSID. We distinguish between variation in shortterm changes in earnings (instability) and variation in longer-term averages (inequality). We use random rematching of spouses as a way to tease out the magnitude of the effects of positive assortative matching on observables and coordination of labor supply within families on these trends.

Comparison of the inequality of couples' earnings relative to husbands' earnings suggests that wives' earnings have muted the rise of permanent earnings inequality as well as smoothed over earnings instability at the family level. We find, however, that coordination of spouses' labor supply decisions and positive assortative matching played only a minor role in determining overall trends in earnings inequality and earnings instability among married couples. 


\section{References}

Attanasio, O., H. Low, and V. Sanchez-Marcos (2008): "Explaining Changes in Female Labor Supply in a Life-Cycle Model," American Economic Review, 98(4), 1517-1552.

Autor, D., And L. KATz (1999): "Changes in the Wage Structure and Earnings Inequality," in Handbook of Labor Economics, Vol.3, ed. by O. Ashenfelter, and D. Card, chap. 26, pp. 1463-1555. North Holland.

Autor, D., L. F. Katz, and M. S. Kearney (2008): "Trends in U.S. Wage Inequality: Revising the Revisionists," Review of Economics and Statistics, 90(2), 300-323.

Blundell, R., L. Pistaferri, and I. Preston (2008): "Consumption Inequality and Partial Insurance," American Economic Review, 98(5), 1887-1921.

Cameron, S., and J. Tracy (1998): "Earnings Variability in the United States: An Examination Using Matched CPS Data," Mimeo.

Cancian, M., S. Danziger, and P. Gottschalk (1993): "Working Wives and Family Income Inequality Among Married Couples," in Uneven Tides. Rising Inequality in America, ed. by S. Danziger, and P. Gottschalk, pp. 195-223. Russell Sage Foundation, New York.

Cancian, M., and D. Reed (1999): “The Impact of Wives' Earnings on Income Inequality: Issues and Estimates," Demography, 36(2), 173-184.

Celik, S., C. Juhn, K. McCue, and J. Thompson (2012): "Recent Trends in Earnings Volatility: Evidence from Survey and Administrative Data," The B.E. Journal of Economic Analysis and Policy, 12(2).

Dahl, M., T. DeLeire, and J. Schwabish (2008): "Recent Trends in the Variability of Individual Earnings and Household Income," Mimeo, Congressional Budget Office.

Devereux, P. (2004): "Changes in Relative Wages and Family Labor Supply," Journal of Human Resources, 39, 696-722.

Dynan, K., D. Elmendorf, and D. Sichel (2012): "The Evolution of Household Income Volatility," The B.E. Journal of Economic Analysis and Policy, 12(2).

Eika, L., M. Mogstad, And B. Zafar (2014): "Educational Assortative Mating and Household Income Inequality," NBER Working Paper 20271.

Gottschalk, P., And R. Moffitt (1994): "The Growth of Earnings Instability in the U.S. Labor Market," Brookings Papers on Economic Activity, 2, 217-254.

Greenwood, J., N. Guner, G. Korchakov, and C. Santos (2014): "Marry You Like: Assortative Mating and Income Inequality," American Economic Review, Papers and Proceedings, 104(5), 348-353.

Guvenen, F., S. Ozkan, and J. Song (2014): "The Nature of Countercyclical Income Risk," Journal of Political Economy, 122(3), 621-660. 
HAIDER, S. (2001): "Earnings Instability and Earnings Inequality of Males in the United States: 1967-1991," Journal of Labor Economics, 19, 799-836.

Heathcote, J., F. Perri, and G. L. Violante (2010): "Unequal We Stand: An Empirical Analysis of Economic Inequality in the United States: 1967-2006," Review of Economic Dynamics, 13(1), 15-51.

Heathcote, J., K. Storesletten, and G. L. Violante (2010): "The Macroeconomic Implications of Rising Wage Inequality in the Unites States," Journal of Political Economy, 118(4), 681-722.

Hyslop, D. (2001): "Rising U.S. Earnings Inequality and Family Labor Supply: The Covariance Structure of Intrafamily Earnings," American Economic Review, 91(4), 755-777.

Kopczuk, W., E. Saez, And J. Song (2010): "Earnings Inequality and Mobility in the United States: Evidence From Social Security Data Since 1937," Quarterly Journal of Economics, 125(1), 91-128.

LundBerg, S. (1985): “The Added Worker Effect," Journal of Labor Economics, 3(1), 11-37.

(1988): "Labor Supply of Husbands and Wives: A Simultaneous Equations Approach," Review of Economics and Statistics, 70(2), 224-235.

Mare, R. (1991): "Five Decades of Educational Assortative Mating," American Sociological Review, 56(1), 15-32.

Monti, H., and G. Gathright (2013): "Measuring earnings instability using survey and administrative data," Discussion paper, Working Paper, US Census.

Pencavel, J. (1988): "Assortative Mating by Schooling and the Work Behavior of Wives and Husbands," American Economic Review, 88(2), 326-329.

(2006a): "Earnings Inequality and Market Work in Husband-Wife Families," IZA Discussion Paper No. 2235.

(2006b): "A Life Cycle Perspective on Changes in Earnings Inequality Among Married Men and Women," Review of Economics and Statistics, 88(2), 232-242.

Sabelhaus, J., And J. Song (2010): "The Great Moderation in Micro Labor Earnings," Journal of Monetary Economics, 57(4), 391-403.

Shin, D., And G. Solon (2011): "Trends in Men's Earnings Volatility: What Does the Panel Study of Income Dynamics Show?," Journal of Public Economics, 95, 973-982.

Stephens, M. (2002): "Displacement and the Added Worker Effect," Journal of Labor Economics, 30(3), 504-537. 
TABle 1: Permanent VARIAnce of EARnings

\begin{tabular}{|c|c|c|c|c|c|}
\hline & 1980 & 1990 & $\begin{array}{c}2000 / \\
2001\end{array}$ & 2009 & $\begin{array}{c}\Delta(2009- \\
1980), \%\end{array}$ \\
\hline & \multicolumn{5}{|c|}{ SIPP-SSA } \\
\hline Men & 0.314 & 0.416 & 0.479 & 0.571 & 81.8 \\
\hline Husbands & 0.275 & 0.369 & 0.434 & 0.547 & 98.9 \\
\hline Couples & 0.245 & 0.302 & 0.347 & 0.415 & 69.4 \\
\hline \multirow[t]{2}{*}{ Couples, cond swap } & 0.254 & 0.311 & 0.352 & 0.431 & 69.7 \\
\hline & {$[0.248,0.261]$} & {$[0.305,0.318]$} & {$[0.341,0.361]$} & {$[0.415,0.449]$} & {$[61.4,77.4]$} \\
\hline \multirow[t]{3}{*}{ Couples, uncond swap } & 0.246 & 0.292 & 0.331 & 0.411 & 67.2 \\
\hline & {$[0.240,0.252]$} & {$[0.285,0.297]$} & {$[0.325,0.340]$} & {$[0.395,0.427]$} & {$[60.9,74.8]$} \\
\hline & \multicolumn{5}{|c|}{ PSID } \\
\hline Men & 0.193 & 0.274 & 0.319 & 0.405 & 110.2 \\
\hline Husbands & 0.185 & 0.236 & 0.282 & 0.353 & 90.7 \\
\hline Couples & 0.177 & 0.208 & 0.227 & 0.292 & 64.5 \\
\hline \multirow[t]{2}{*}{ Couples, cond. swap } & 0.174 & 0.207 & 0.234 & 0.286 & 65.2 \\
\hline & {$[0.159,0.191]$} & {$[0.191,0.233]$} & {$[0.218,0.251]$} & {$[0.265,0.311]$} & {$[46.3,88.7]$} \\
\hline \multirow[t]{2}{*}{ Couples, uncond. swap } & 0.172 & 0.202 & 0.228 & 0.276 & 61.2 \\
\hline & {$[0.157,0.190]$} & {$[0.186,0.222]$} & {$[0.212,0.248]$} & {$[0.255,0.300]$} & {$[41.3,86.0]$} \\
\hline
\end{tabular}

Notes: The conditionally and unconditionally swapped estimates are based on averages across 100 simulations. To construct an approximate 95\% confidence interval, we use the 2nd and 98th percentiles of the simulated distributions. For the column reporting percent changes, we take the percentage change between 1980 and 2009 for each simulation, and then use the 2nd and 98th percentiles from the distribution of changes as the bounds on the confidence interval. 
TABle 2: Transitory VARIANCE OF EARNings

\begin{tabular}{|c|c|c|c|c|c|}
\hline & 1980 & 1990 & $\begin{array}{c}2000 / \\
2001\end{array}$ & 2009 & $\begin{array}{c}\Delta(2009- \\
1980), \%\end{array}$ \\
\hline & \multicolumn{5}{|c|}{ SIPP-SSA } \\
\hline Men & 0.120 & 0.115 & 0.111 & 0.124 & 3.3 \\
\hline Husbands & 0.103 & 0.098 & 0.090 & 0.117 & 13.6 \\
\hline Couples & 0.077 & 0.058 & 0.051 & 0.058 & -24.7 \\
\hline \multirow[t]{2}{*}{ Couples, cond swap } & 0.077 & 0.059 & 0.052 & 0.063 & -18.3 \\
\hline & {$[0.075,0.080]$} & {$[0.058,0.061]$} & {$[0.050,0.054]$} & {$[0.058,0.068]$} & {$[-25.8,-10.9$} \\
\hline \multirow[t]{3}{*}{ Couples, uncond swap } & 0.078 & 0.060 & 0.054 & 0.064 & -17.4 \\
\hline & {$[0.075,0.080]$} & {$[0.059,0.062]$} & {$[0.052,0.056]$} & {$[0.060,0.068]$} & {$[-23.6,-11.1$} \\
\hline & \multicolumn{5}{|c|}{ PSID } \\
\hline Men & 0.037 & 0.043 & 0.079 & 0.088 & 134.5 \\
\hline Husbands & 0.031 & 0.036 & 0.066 & 0.070 & 123.0 \\
\hline Couples & 0.025 & 0.027 & 0.039 & 0.040 & 64.3 \\
\hline \multirow[t]{2}{*}{ Couples, cond. swap } & 0.026 & 0.027 & 0.041 & 0.042 & 61.7 \\
\hline & {$[0.021,0.032]$} & {$[0.023,0.033]$} & {$[0.035,0.047]$} & {$[0.036,0.048]$} & {$[25.5,109.1]$} \\
\hline \multirow{2}{*}{ Couples, uncond. swap } & 0.026 & 0.028 & 0.041 & 0.041 & 58.0 \\
\hline & {$[0.021,0.033]$} & {$[0.023,0.032]$} & {$[0.035,0.048]$} & {$[0.036,0.048]$} & {$[15.8,102.1]$} \\
\hline
\end{tabular}

See notes to Table 1 . 
Table 3: Permanent variance of Earnings For COUPles With NON-COlLege GRadUATE HUSBANDS

\begin{tabular}{|c|c|c|c|c|c|}
\hline & 1980 & 1990 & $\begin{array}{c}2000 / \\
2001\end{array}$ & 2009 & $\begin{array}{c}\Delta(2009- \\
1980), \%\end{array}$ \\
\hline & \multicolumn{5}{|c|}{ SIPP-SSA } \\
\hline Men & 0.296 & 0.387 & 0.422 & 0.511 & 72.6 \\
\hline Husbands & 0.261 & 0.343 & 0.371 & 0.459 & 75.9 \\
\hline Couples & 0.233 & 0.284 & 0.306 & 0.359 & 54.1 \\
\hline \multirow[t]{2}{*}{ Couples, cond swap } & 0.246 & 0.303 & 0.317 & 0.358 & 45.5 \\
\hline & {$[0.237,0.256]$} & {$[0.294,0.314]$} & {$[0.303,0.335]$} & {$[0.332,0.386]$} & {$[32.7,60.2]$} \\
\hline \multirow[t]{3}{*}{ Couples, uncond swap } & 0.241 & 0.286 & 0.294 & 0.345 & 43.2 \\
\hline & {$[0.233,0.251]$} & {$[0.276,0.295]$} & {$[0.284,0.305]$} & {$[0.320,0.374]$} & {$[32.0,53.5]$} \\
\hline & \multicolumn{5}{|c|}{ PSID } \\
\hline Men & 0.184 & 0.234 & 0.252 & 0.344 & 86.8 \\
\hline Husbands & 0.177 & 0.204 & 0.220 & 0.299 & 69.4 \\
\hline Couples & 0.171 & 0.192 & 0.200 & 0.264 & 54.6 \\
\hline Couples, cond. swap & 0.167 & 0.182 & 0.193 & 0.248 & 48.3 \\
\hline \multirow{3}{*}{ Couples, uncond. swap } & {$[0.147,0.191]$} & {$[0.163,0.197]$} & {$[0.175,0.213]$} & {$[0.222,0.273]$} & {$[29.6,73.9]$} \\
\hline & 0.168 & 0.181 & 0.189 & 0.240 & 43.3 \\
\hline & {$[0.150,0.200]$} & {$[0.160,0.201]$} & {$[0.172,0.204]$} & {$[0.215,0.270]$} & {$[24.3,70.2]$} \\
\hline
\end{tabular}

See notes to Table 1 . 
Table 4: Permanent variance of earnings for COUPles With College-graduate HUSBANDS

\begin{tabular}{|c|c|c|c|c|c|}
\hline & 1980 & 1990 & $\begin{array}{l}2000 / \\
2001\end{array}$ & 2009 & $\begin{array}{c}\Delta(2009- \\
1980), \%\end{array}$ \\
\hline & \multicolumn{5}{|c|}{ SIPP-SSA } \\
\hline Men & 0.283 & 0.357 & 0.434 & 0.501 & 77.0 \\
\hline Husbands & 0.229 & 0.303 & 0.390 & 0.483 & 110.9 \\
\hline Couples & 0.190 & 0.215 & 0.275 & 0.327 & 72.1 \\
\hline \multirow[t]{2}{*}{ Couples, cond swap } & 0.214 & 0.261 & 0.310 & 0.396 & 84.9 \\
\hline & {$[0.208,0.222]$} & {$[0.254,0.267]$} & {$[0.300,0.322]$} & {$[0.376,0.419]$} & {$[70.6,95.6]$} \\
\hline \multirow[t]{3}{*}{ Couples, uncond swap } & 0.214 & 0.256 & 0.308 & 0.390 & 82.1 \\
\hline & {$[0.208,0.222]$} & {$[0.249,0.262]$} & {$[0.299,0.319]$} & {$[0.371,0.414]$} & {$[70.0,91.9]$} \\
\hline & \multicolumn{5}{|c|}{ PSID } \\
\hline Men & 0.150 & 0.242 & 0.326 & 0.384 & 156.4 \\
\hline Husbands & 0.124 & 0.199 & 0.270 & 0.313 & 152.6 \\
\hline Couples & 0.126 & 0.142 & 0.181 & 0.237 & 87.7 \\
\hline Couples, cond. swap & 0.127 & 0.171 & 0.221 & 0.250 & 98.8 \\
\hline \multirow{3}{*}{ Couples, uncond. swap } & {$[0.104,0.154]$} & {$[0.141,0.208]$} & {$[0.186,0.258]$} & {$[0.225,0.298]$} & {$[59.1,146.8]$} \\
\hline & 0.128 & 0.171 & 0.217 & 0.246 & 94.3 \\
\hline & {$[0.108,0.151]$} & {$[0.136,0.215]$} & {$[0.190,0.257]$} & {$[0.213,0.289]$} & {$[54.7,144.4]$} \\
\hline
\end{tabular}

See notes to Table 1 . 
TABle 5: Gini COefFicients

\begin{tabular}{|c|c|c|c|c|c|}
\hline & 1980 & 1990 & $\begin{array}{c}2000 / \\
2001\end{array}$ & 2009 & $\begin{array}{c}\Delta(2009- \\
1980), \%\end{array}$ \\
\hline & \multicolumn{5}{|c|}{ SIPP-SSA } \\
\hline Men & 0.259 & 0.305 & 0.338 & 0.365 & 40.9 \\
\hline Husbands & 0.243 & 0.287 & 0.326 & 0.358 & 47.3 \\
\hline Couples & 0.240 & 0.268 & 0.298 & 0.326 & 35.8 \\
\hline Couples, cond swap & {$[0.245,0.249]$} & {$[0.271,0.275]$} & {$[0.299,0.306]$} & {$[0.324,0.336]$} & {$[30.8,36.8]$} \\
\hline Couples, cond swap & 0.247 & 0.273 & 0.303 & 0.329 & 33.5 \\
\hline Couples, uncond swap & {$[0.239,0.244]$} & {$[0.260,0.264]$} & {$[0.288,0.293]$} & {$[0.311,0.322]$} & {$[28.9,33.7]$} \\
\hline \multirow[t]{2}{*}{ Couples, uncond swap } & 0.242 & 0.262 & 0.290 & 0.317 & 31.2 \\
\hline & \multicolumn{5}{|c|}{ PSID } \\
\hline Men & 0.227 & 0.278 & 0.307 & 0.332 & 46.3 \\
\hline Husbands & 0.222 & 0.261 & 0.290 & 0.316 & 42.4 \\
\hline Couples & 0.218 & 0.242 & 0.259 & 0.286 & 30.9 \\
\hline \multirow{2}{*}{ Couples, cond. swap } & 0.218 & 0.246 & 0.264 & 0.289 & 32.8 \\
\hline & {$[0.210,0.227]$} & {$[0.237,0.258]$} & {$[0.257,0.271]$} & {$[0.280,0.296]$} & {$[26.3,38.2]$} \\
\hline \multirow[t]{2}{*}{ Couples, uncond. swap } & 0.215 & 0.237 & 0.254 & 0.277 & 29.1 \\
\hline & {$[0.207,0.224]$} & {$[0.229,0.247]$} & {$[0.246,0.264]$} & {$[0.267,0.286]$} & {$[22.0,35.9]$} \\
\hline
\end{tabular}

See notes to Table 1 . 


\section{Figure 1: Permanent VARIANCE FOR MEN}
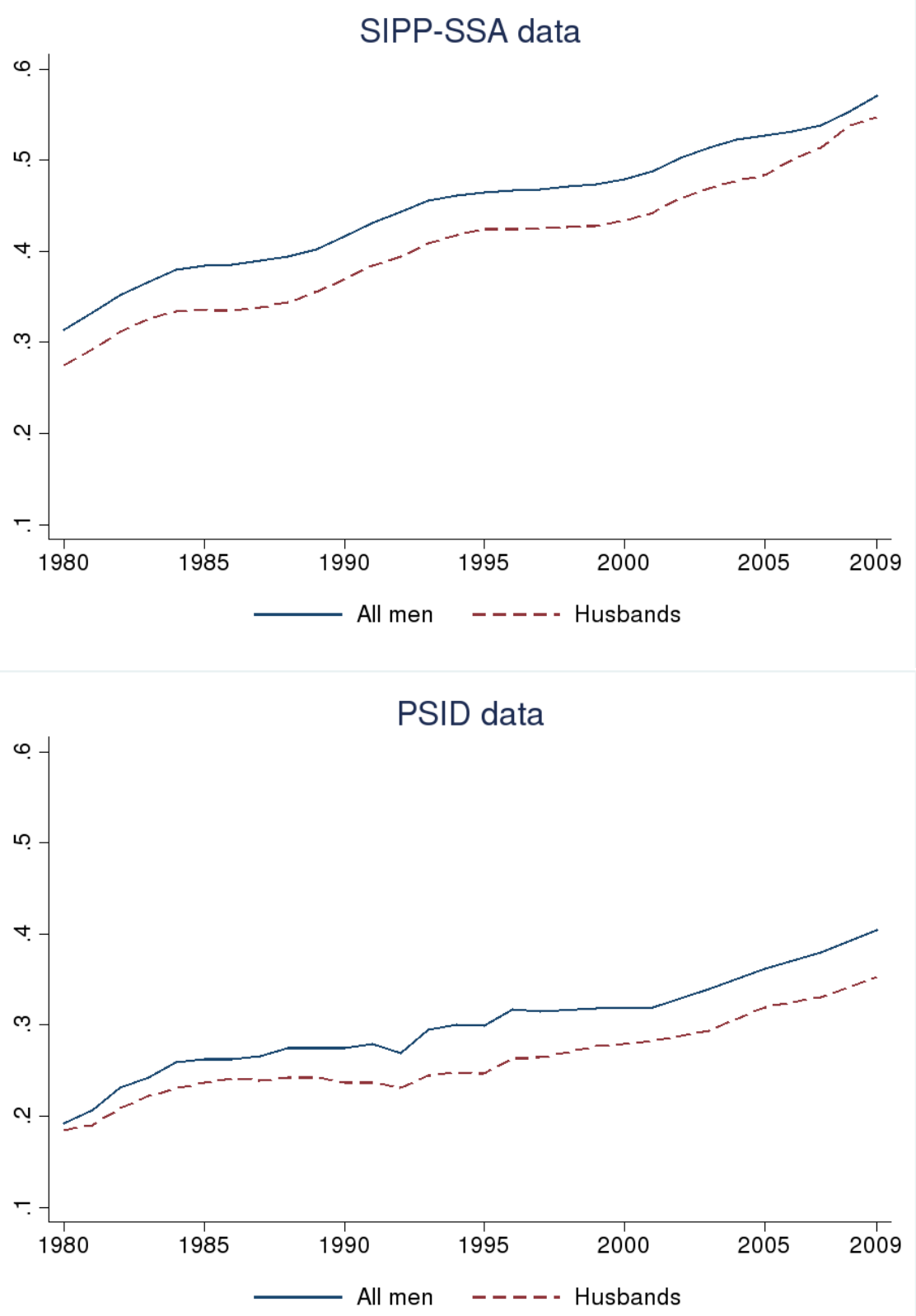
Figure 2: Transitory variance for Men
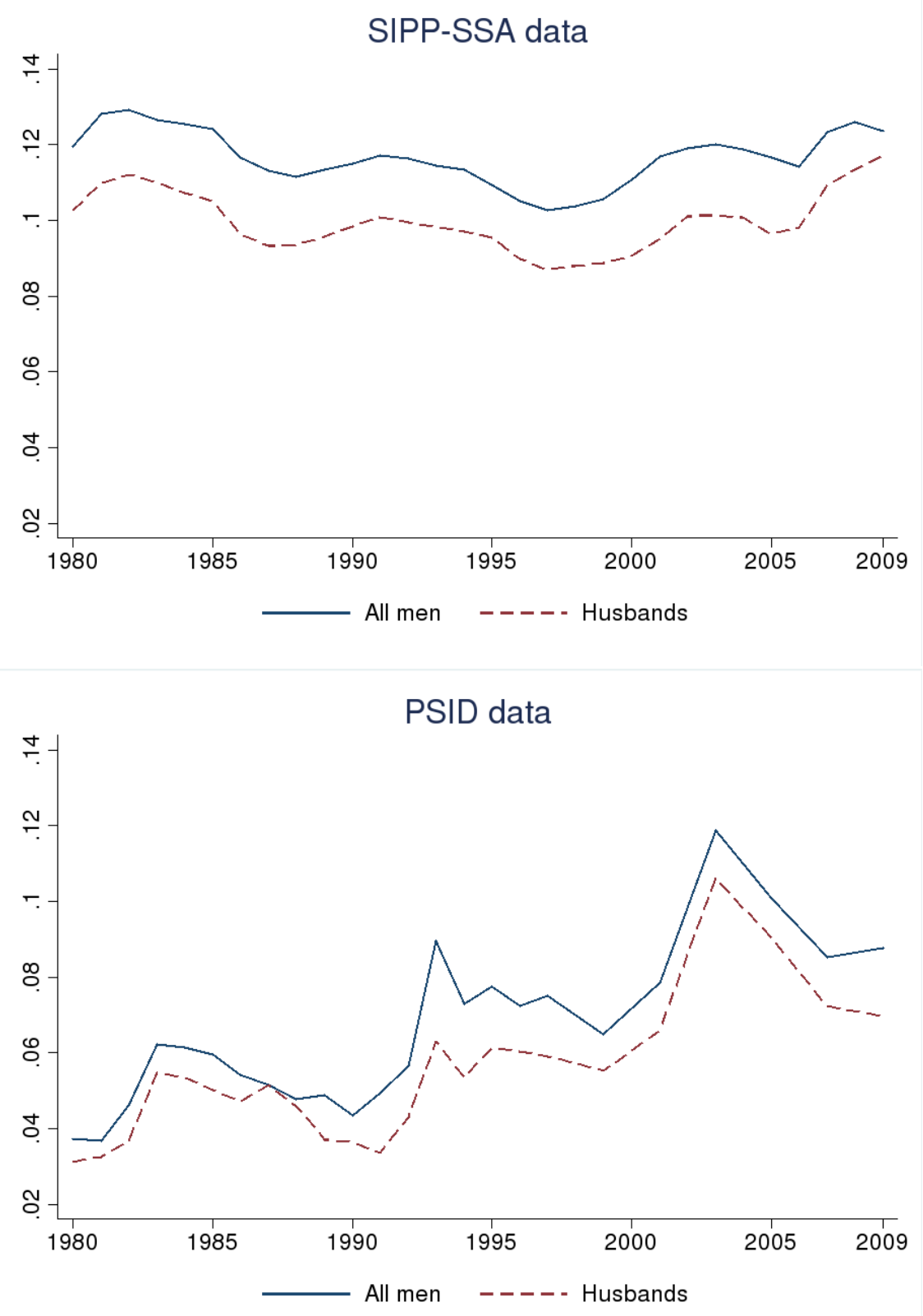
Figure 3: Permanent variance for Couples
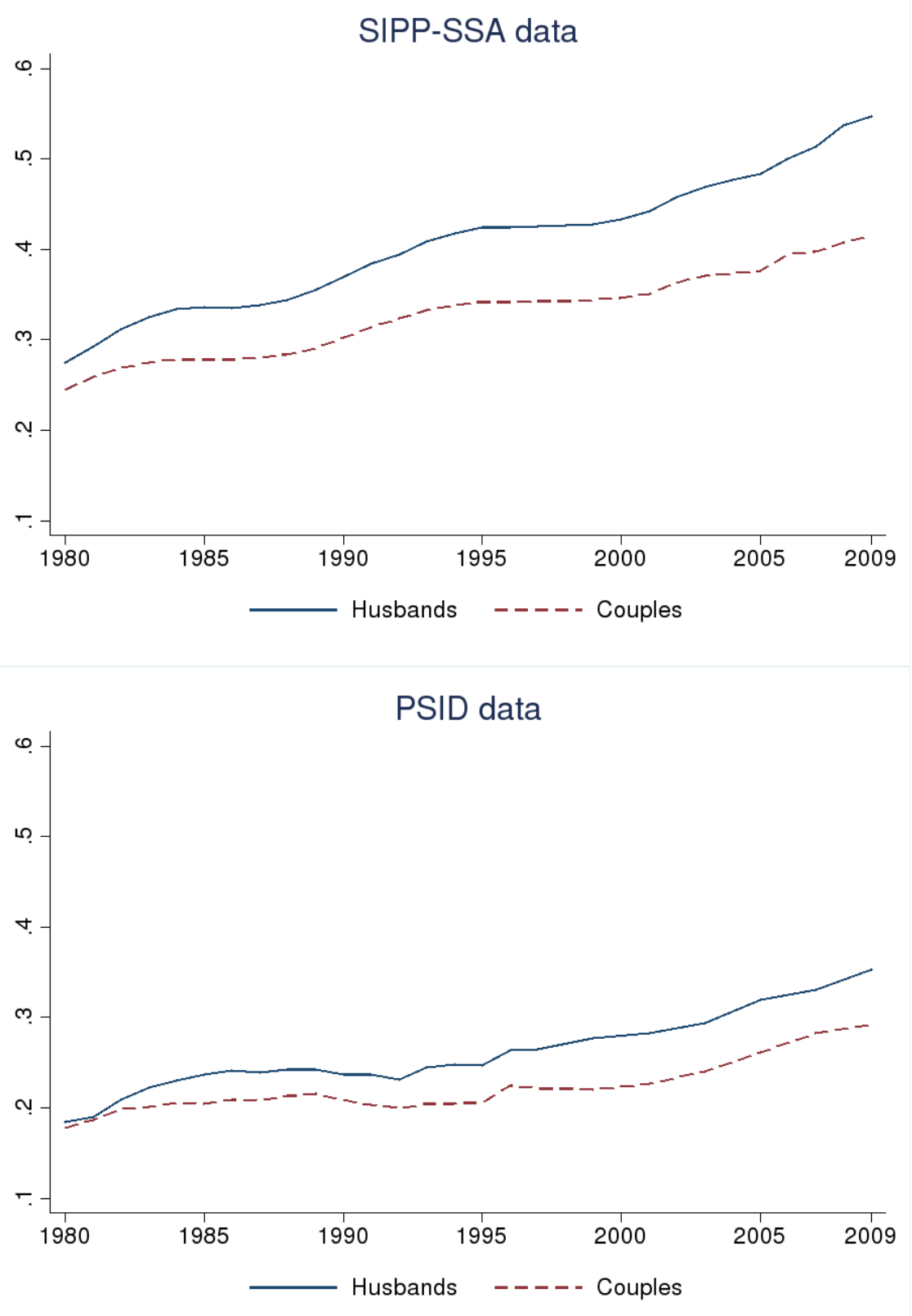
Figure 4: Transitory VARIANCE FOR COUPles
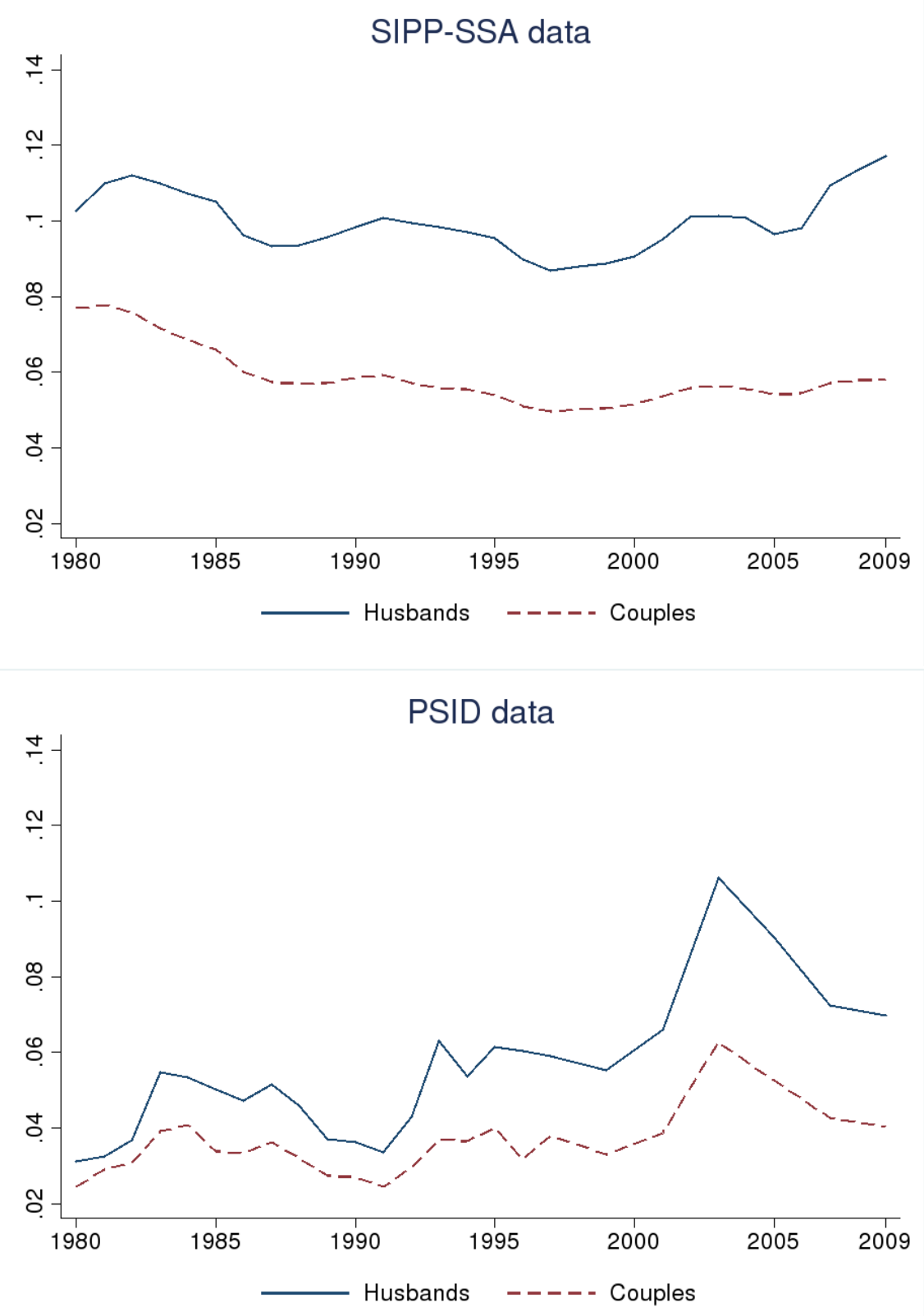
Figure 5: Permanent variance For aCtual AND Rematched COUPles
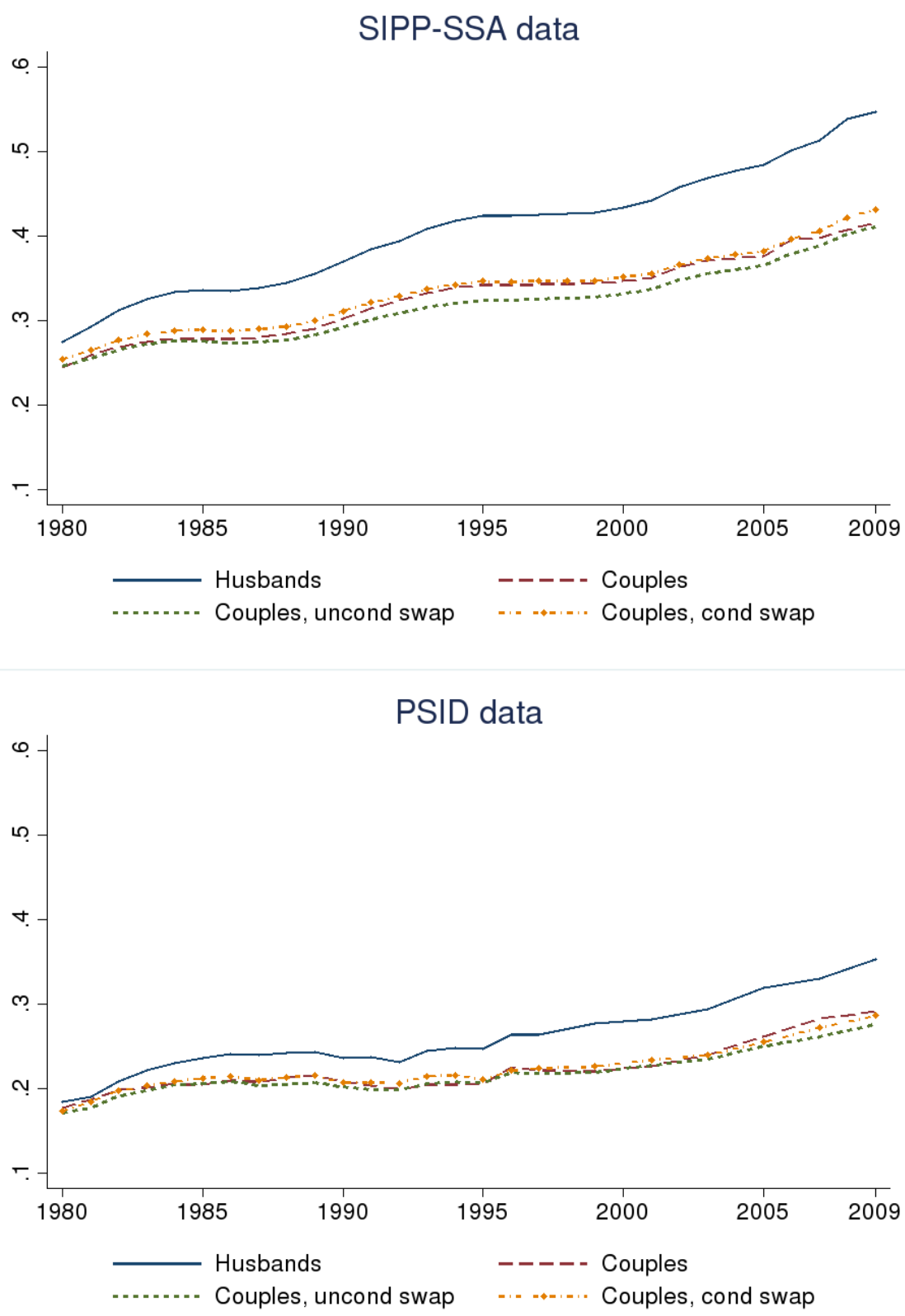
Figure 6: Correlation, Permanent incomes of Husband And Wife
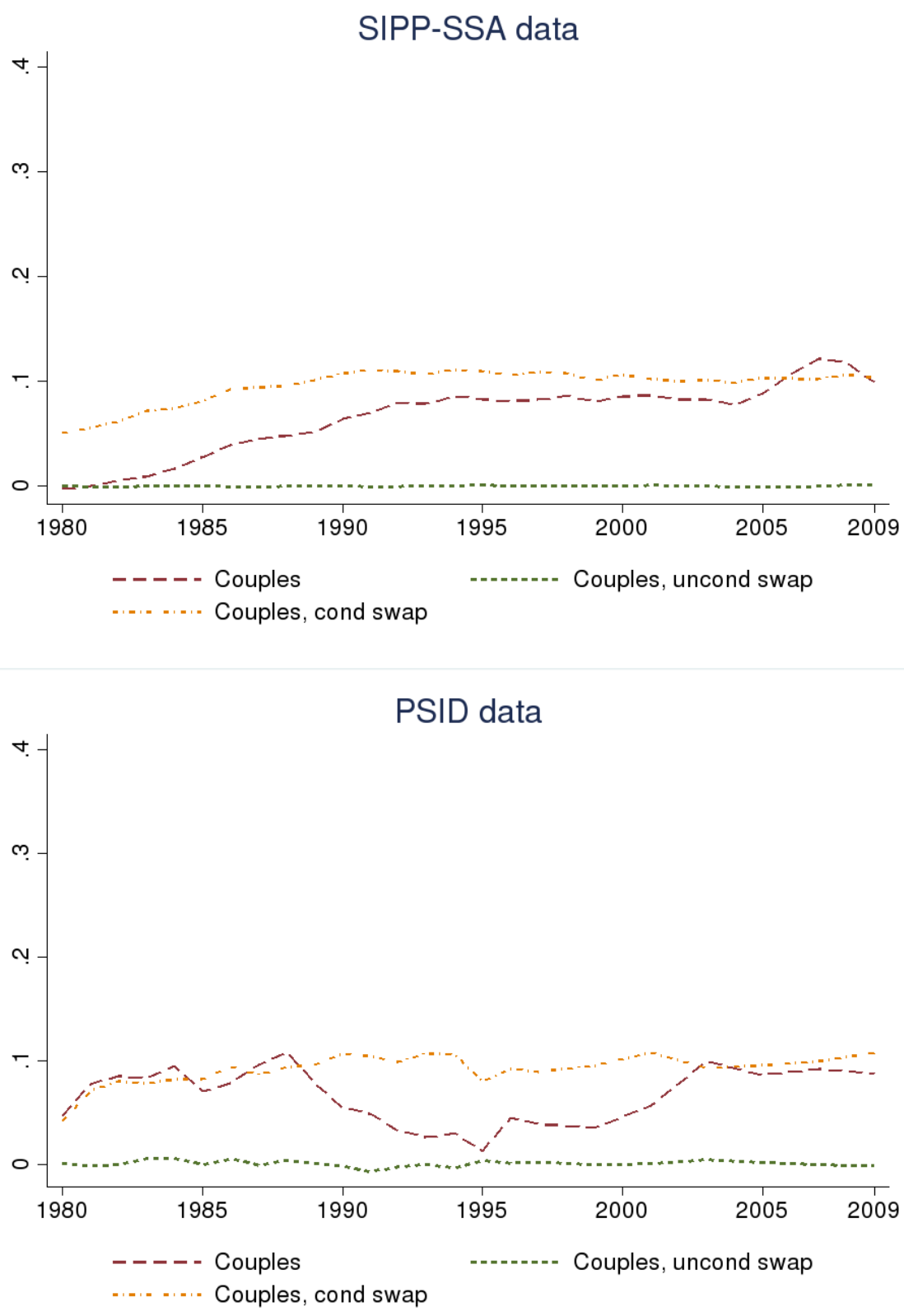
Figure 7: Permanent variance, COUPles With NON-COLlEGE-GRAD husband
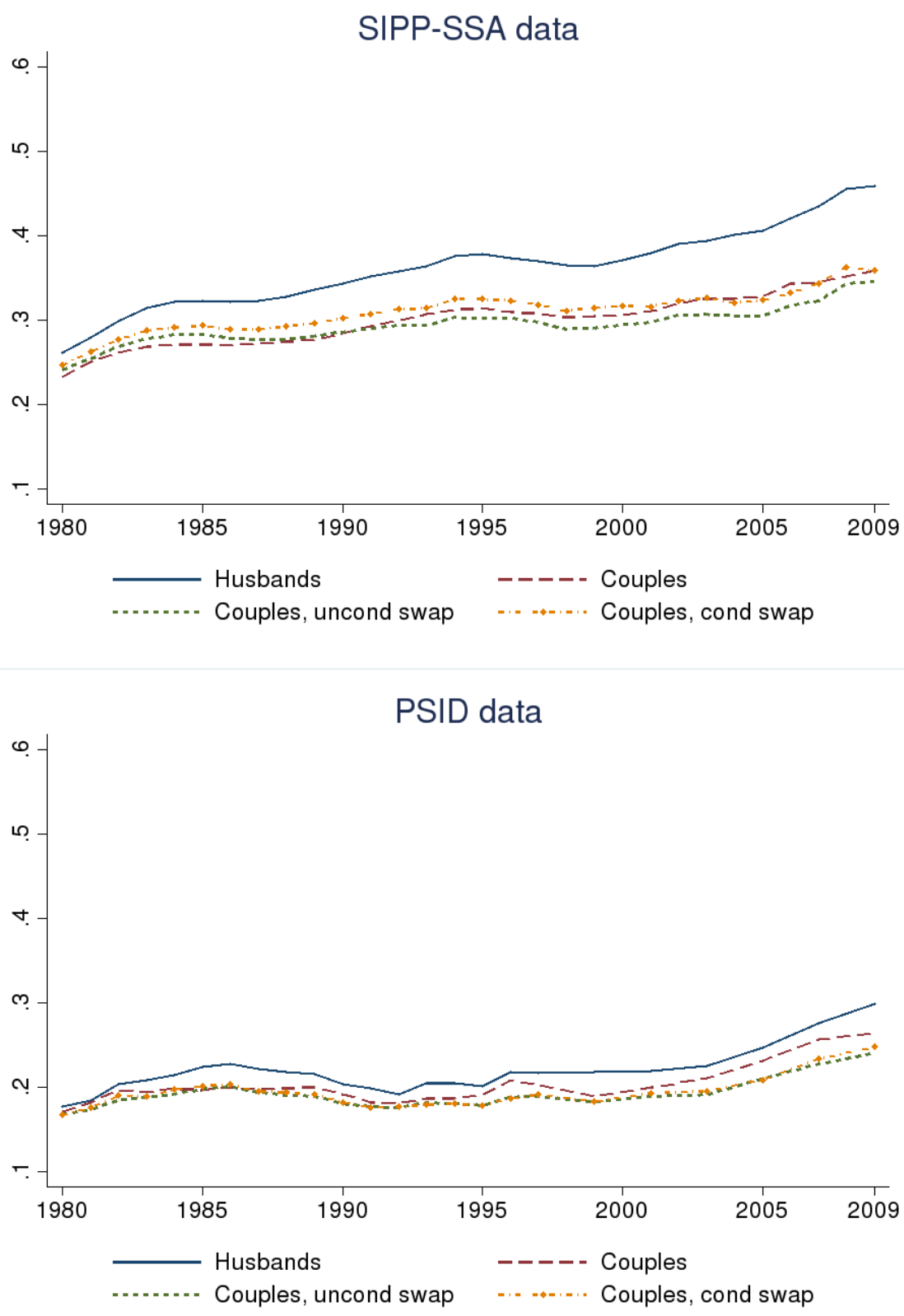
Figure 8: Permanent variance, COUPles With COllege-Graduate husband
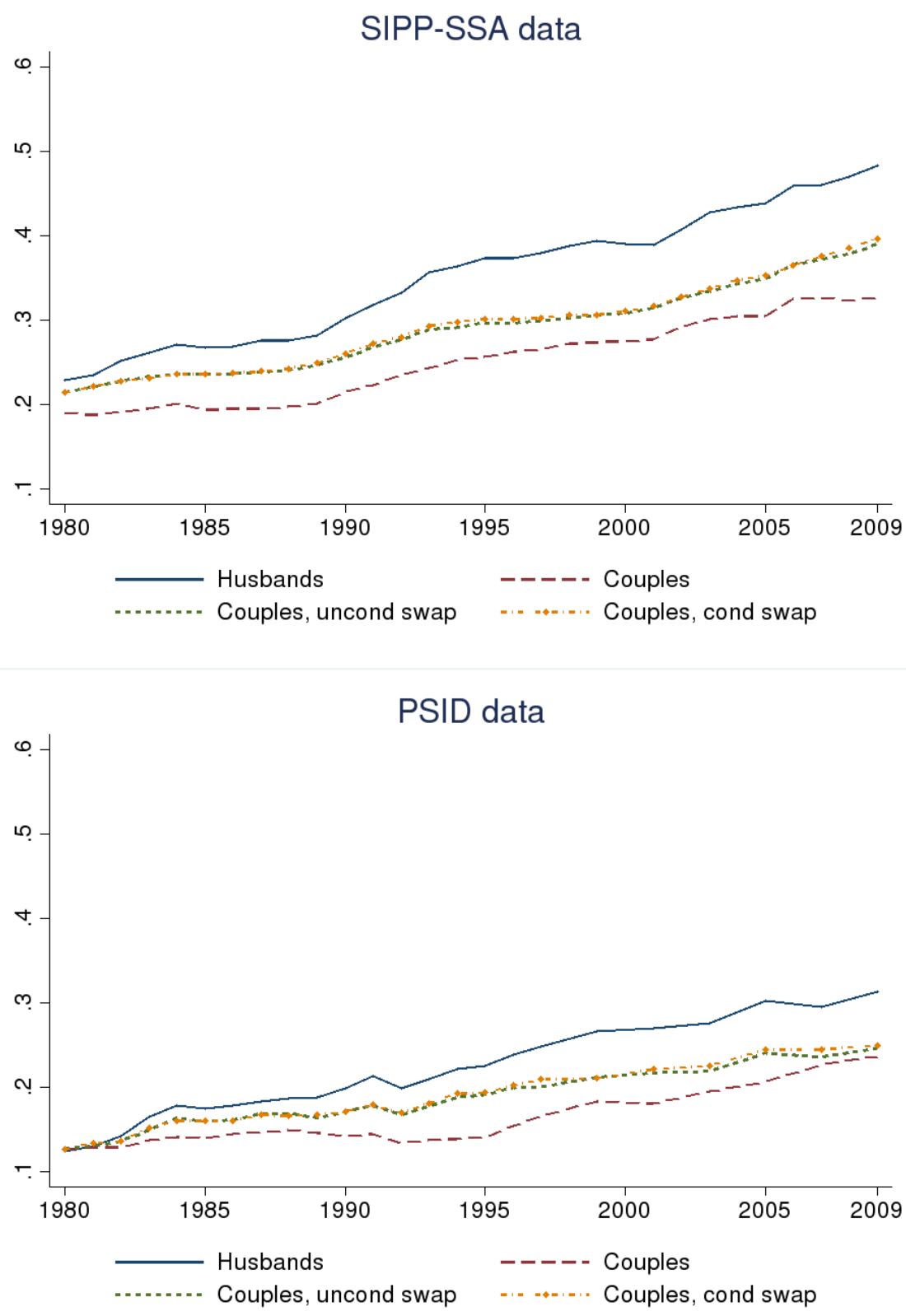
Figure 9: Transitory VARIANCE FOR ACTUAL AND REMATCHED COUPLES
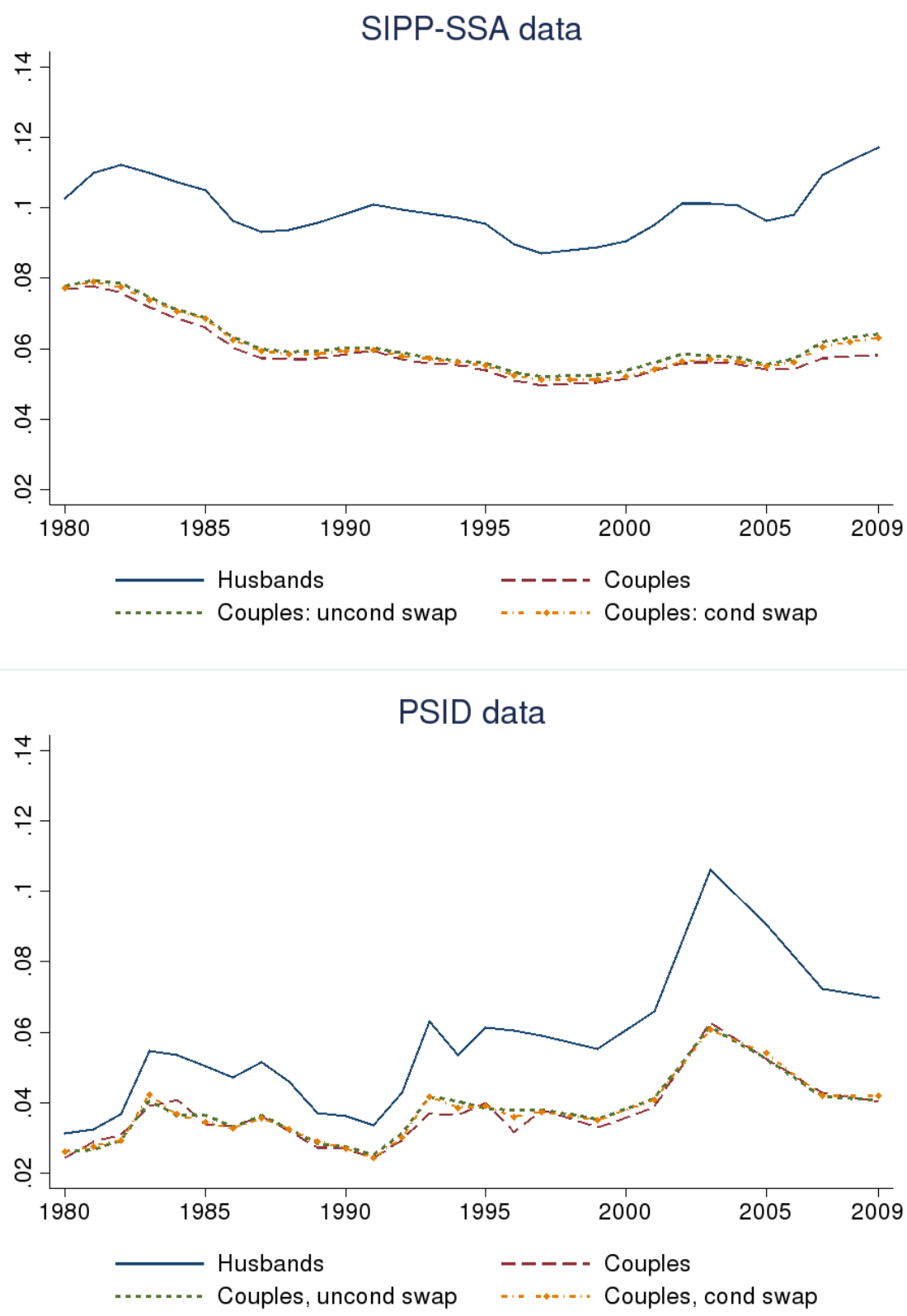
Figure 10: Gini COEFFicients For ACTUAL AND REMATChed COUPLES
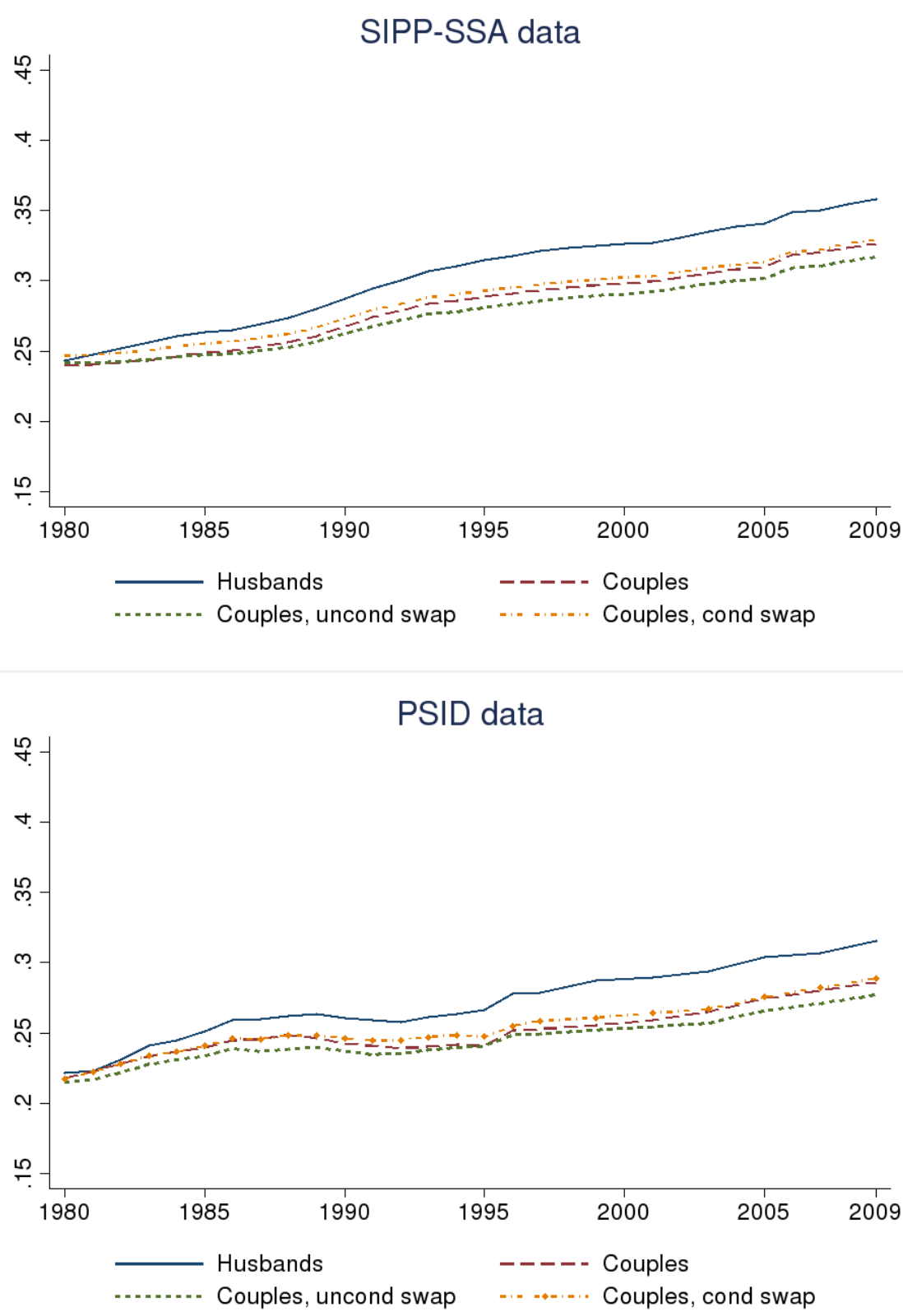
Figure 11: Permanent variances for aCtual and Rematched Couples, Hyslop's SELECTION RULES
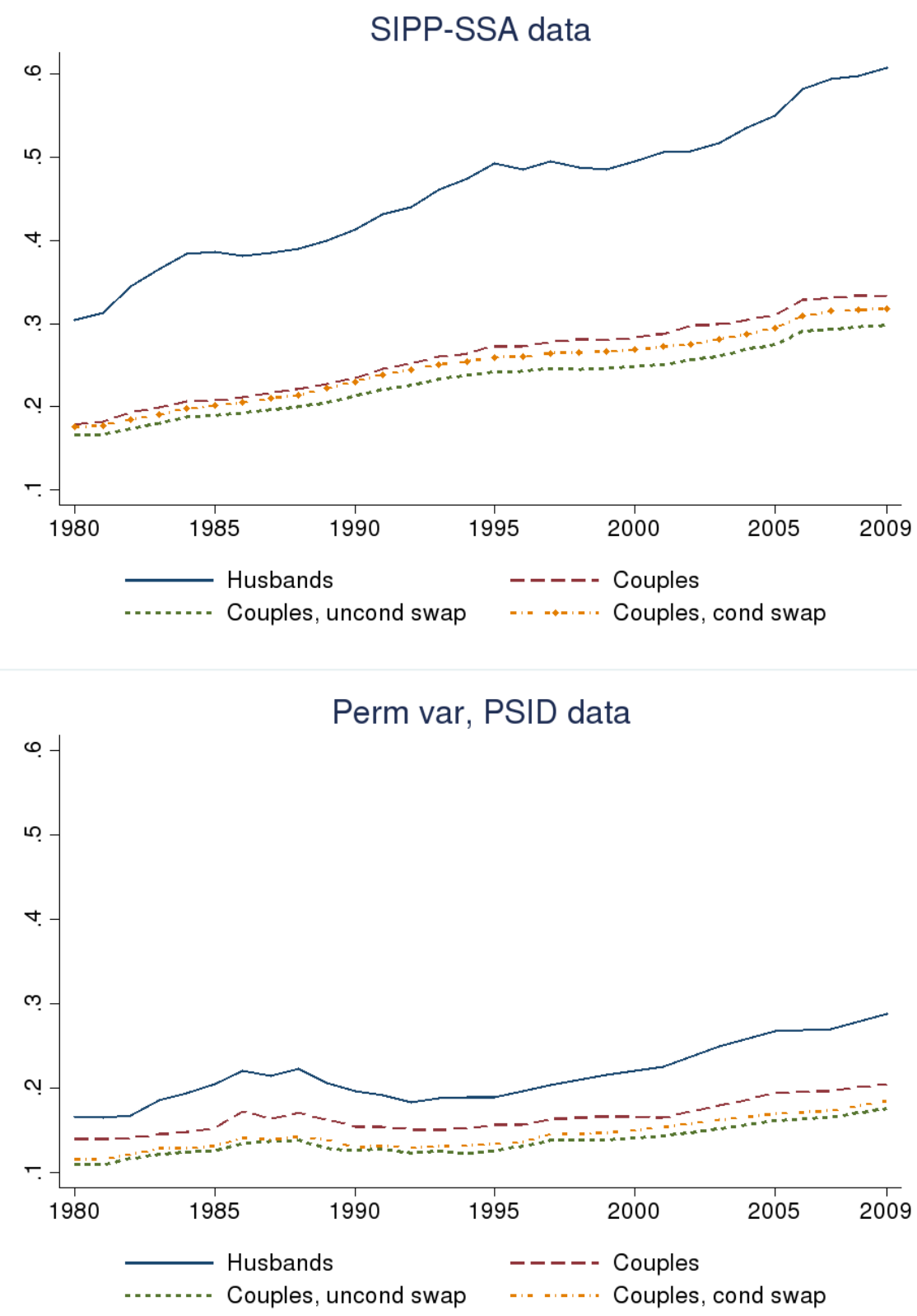
Figure 12: Gini COEFficients for ACtuAl And REMATChed COUPles, Greenwood ET AL.'S SELECTION RULES
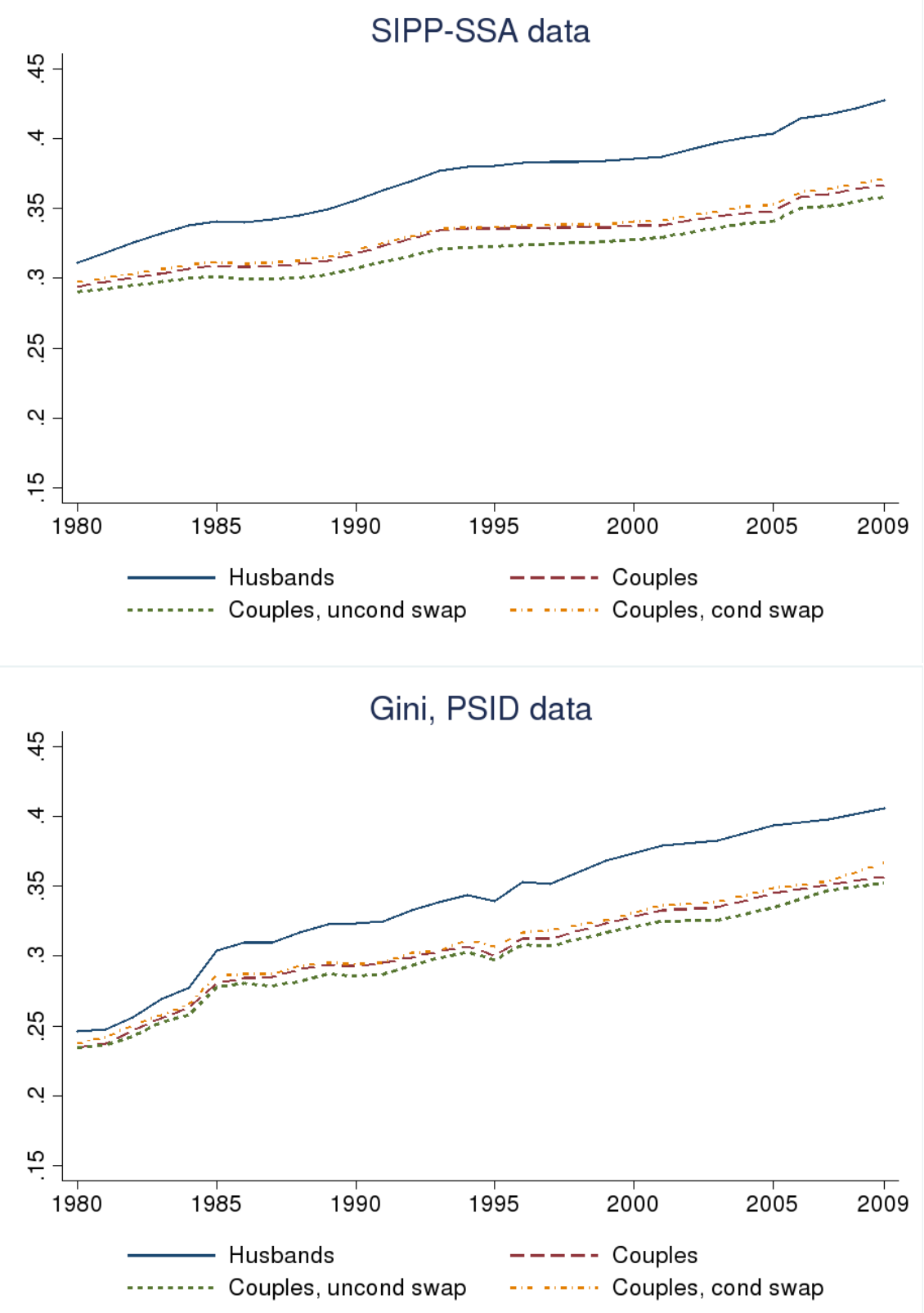
Figure 13: Correlation, Permanent incomes of Husband AND Wife

\section{SIPP-SSA data}
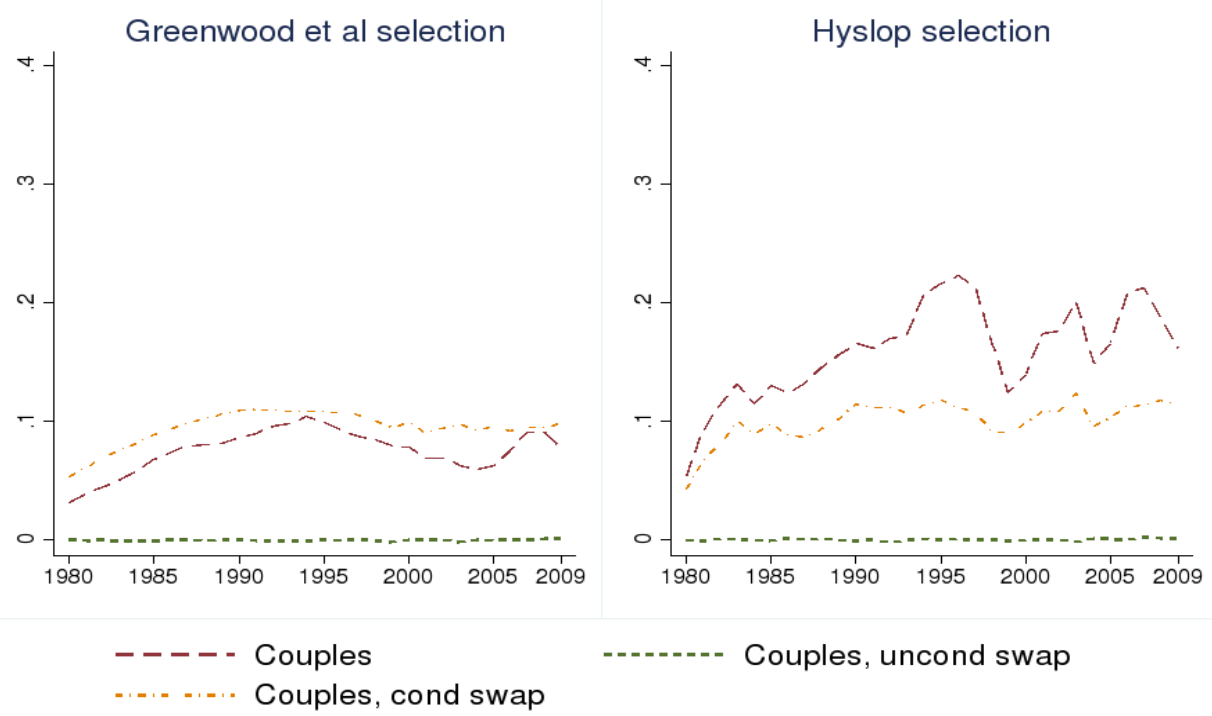

\section{PSID data}
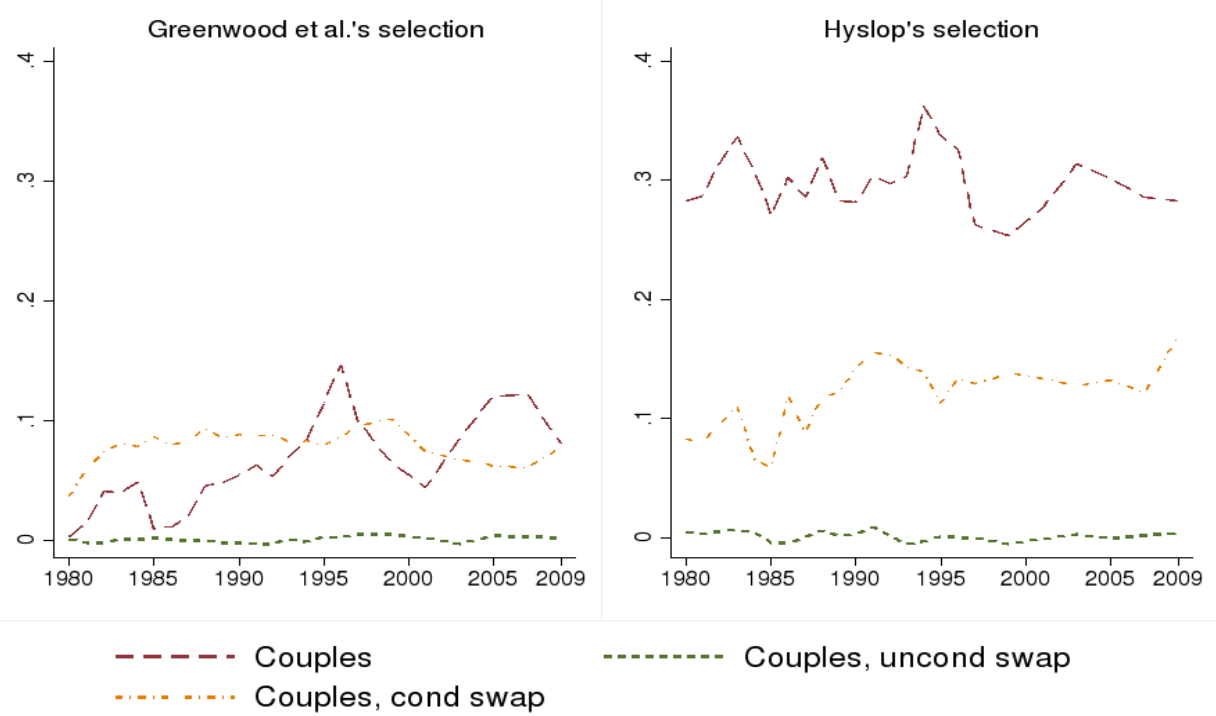